\title{
Tectonic features of the incipient arc-continent collision zone of Taiwan: Implications for seismicity
}

\author{
Andrew T. Lin ${ }^{\mathrm{a}, *}$, Bochu Yao ${ }^{\mathrm{b}}$, Shu-Kun Hsu ${ }^{\mathrm{a}}$, Char-Shine Liu ${ }^{\mathrm{c}}$, Chi-Yue Huang ${ }^{\mathrm{d}}$ \\ a Department of Earth Sciences, National Central University, Chungli, Taiwan \\ b Guangzhou Marine Geological Survey, Ministry of Land and Resource, Guangzhou 510075, PR China \\ ' Institute of Oceanography, National Taiwan University, Taipei, Taiwan \\ ${ }^{d}$ Department of Earth Sciences, National Cheng Kung University, Tainan, Taiwan
}

\section{A R T I C L E I N F O}

\section{Article history:}

Received 28 June 2008

Received in revised form 17 October 2008

Accepted 3 November 2008

Available online $\mathrm{xxxx}$

\section{Keywords:}

Accretionary wedge

Arc-continent collision

Decollement

Seismicity

Taiwan

\begin{abstract}
A B S T R A C T
Southern Taiwan and its offshore area lie in the region where the Luzon volcanic arc initially collides with the rifted China continental margin. Because of the incipient arc-continent collision, the structures vary markedly along-strike the collision zone so as the patterns of seismicity. We use new seismic reflection profiles and integrate existing data to reveal major tectonic features and potential seismogenic faults of the study area. The accretionary wedge in the incipient arc-continent zone can be divided into the lower slope, upper slope, and backthrust domains, respectively. These structural domains reflect different aspects of wedge deformation, and exhibit significant structural variations along-strike. Reflection seismic data show that the prominent seismogenic structures in the Taiwan incipient collisional wedge include: (1) frontal decollement beneath the lower-slope domain, (2) out-of-sequence thrusts bordering the lower-slope and upper-slope domains, (3) megathrust that cuts into the oceanic (?) basement beneath the upper-slope domain, and (4) the Chaochou-Hengchun faults in the onshore upper-slope domain. Thermal regime for those structures indicates that the megathrust and part of frontal decollement are seismogenic. The geometry of the frontal decollement, out-of-sequence thrusts and megathrust is analogous to those observed along the Nankai prism of Japan, so that they are possibly capable of generating great earthquakes as shown in the Nankai Trough.

Beneath the lower and upper-slope domains off SW Taiwan, the seismicity is characterized by mantle earthquakes with the accretionary wedge being largely aseismic. We interpret the lack of prominent seismicity within the accreted wedge to result from excess fluid pressure that has significantly weakened the wedge materials and fault zones and therefore results in less seismicity. The predominant mantle earthquakes beneath the accretionary wedge, however, may result from water-enriched mantle materials infiltrated during previous Mesozoic subduction event and later rift events. The volatile contents may have significantly reduced the rigidity of the mantle, leading to the mantle being more susceptible for brittle deformation and hence anomalously high seismicity.
\end{abstract}

(c) 2008 Elsevier B.V. All rights reserved.

\section{Introduction}

Subduction zones are sites for great earthquakes $(M>8.0$, e.g., Bilek and Lay, 1999) as illustrated by the December 2004 Sumatra earthquake (Lay et al., 2005). Southern Taiwan and its adjacent offshore is the northern continuation of the Manila subduction system, where the subduction system transforms into an incipient arc-continent collision zone with high seismicity as depicted in Figs. 1 and 2. The historical records of seismicity in the incipient arc-continent zone together with the 2006 offshore Pingtung earthquake doublets (Fig. 1)

\footnotetext{
* Corresponding author. 320 No.300 Chungda Road, Chungli, Taoyuan, Taiwan. E-mail address: andrewl@ncu.edu.tw (A.T. Lin).
}

prove that the actively deforming accretionary wedge is capable of generating large and probably great earthquakes.

The causative faults of the crustal earthquakes may be imaged by geophysical methods, and in some places, they may correspond to tectonic features seen on seafloors. For example, the great earthquakes of 1944 Tonankai ( $M=8.1$, Ichinose et al., 2003) and 1946 Nanakai ( $M=8.3$, Baba et al., 2002) that occurred along the Nankai accretionary prism of Japan, are believed to originate from the reactivation of outof-sequence thrusts (Moore et al., 2001; Park et al., 2002; Moore et al., 2007), and the plate-boundary decollement (Park et al., 2002; Moore et al., 2007) lying beneath the rear wedge. Large thrust earthquakes along subduction zones thus pose a great seismic and perhaps tsunami threat (e.g., Park et al., 2002; Moore et al., 2007).

Previous works have given structural and seismological information on various tectonic domains in the study area. For examples, Reed 
et al. (1992) outlined the first overview of major tectonic features in the offshore incipient arc-continent collision zone. Works of Sun and Liu (1993), Liu et al. (1997), Liu et al. (2004), Huang et al. (2004), Lin et al. (in press) addressed the detail structures off SW Taiwan in the accretionary wedge. Teng et al. (2005) summarized the seismogenic implications for major structures onshore SW Taiwan. Huang et al. (1992), Lundberg et al. (1997), Chi et al. (2003) discussed the structures in the partially deformed forearc basin. Nakamura et al. (1998), McIntosh et al. (2005), and Chi et al. (2003) documented the crustal structures in this tectonic environment. Shyu et al. (2005) related the scale of the structures to the magnitude of potential earthquakes that might be brought about by rupturing seismogenic structures both off the SW and SE coast of Taiwan. Kao et al. (2000) studied the earthquake focal mechanisms in the study area.

Despite all these previous efforts on the structures of the Taiwan incipient arc-continent collision zone, there are still prominent questions that remain to be answered. The most common are: (1) how the structural styles change along-strike as the accretionary

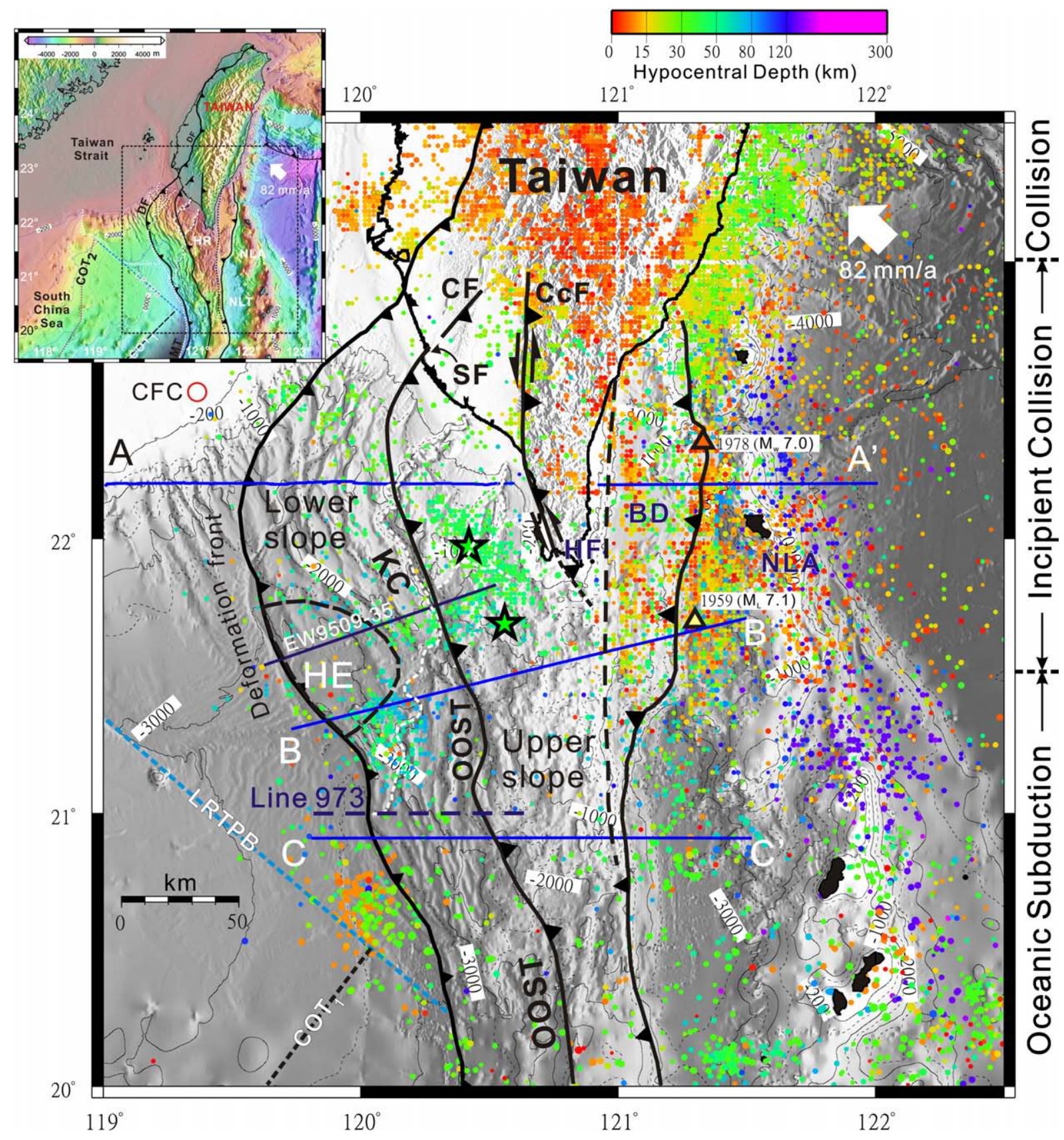

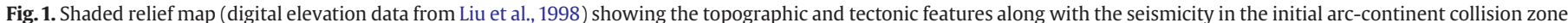

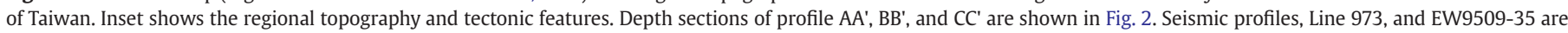

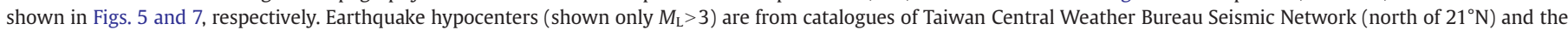

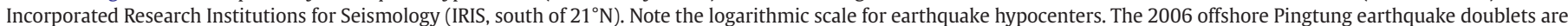

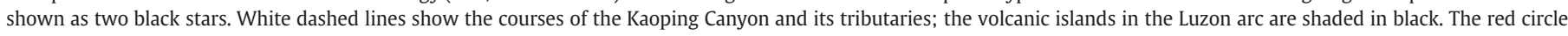

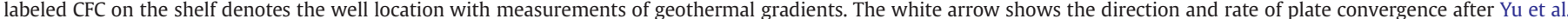

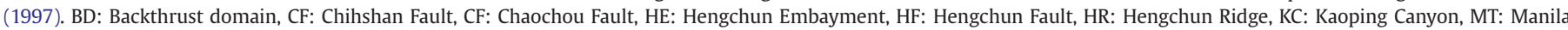

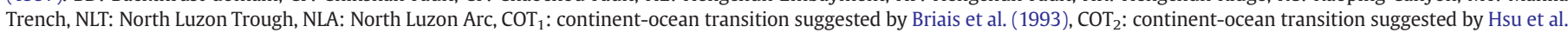
(2004), OOST: Out-of-sequence thrust, LRTPB: Luzon-Ryukyu Transform Plate Boundary, SF: Shoushan Fault. 
wedge transforms from a subduction accretionary wedge in the south into a collisional orogen in the north? (2) what is the nature of major seismogenic structures in the incipient arc-continent collision zone?

This paper attempts to address the questions raised above. The occurrence of the 2006 offshore Pingtung earthquakes also demonstrates that a holistic and updated understanding of major tectonic features in the incipient arc-continent collision zone is warranted.
With the help of a recently acquired multichannel seismic profile, Line 973, we recognize that important tectonic features of frontal decollement, out-of-sequence thrusts, and plate-boundary megathrust exist in the study area and those structures are similar to the ones observed in the Nankai accretionary prism of Japan (e.g., Moore et al., 2007). Implications for seismicity are also addressed based on the structural styles in this tectonic environment.
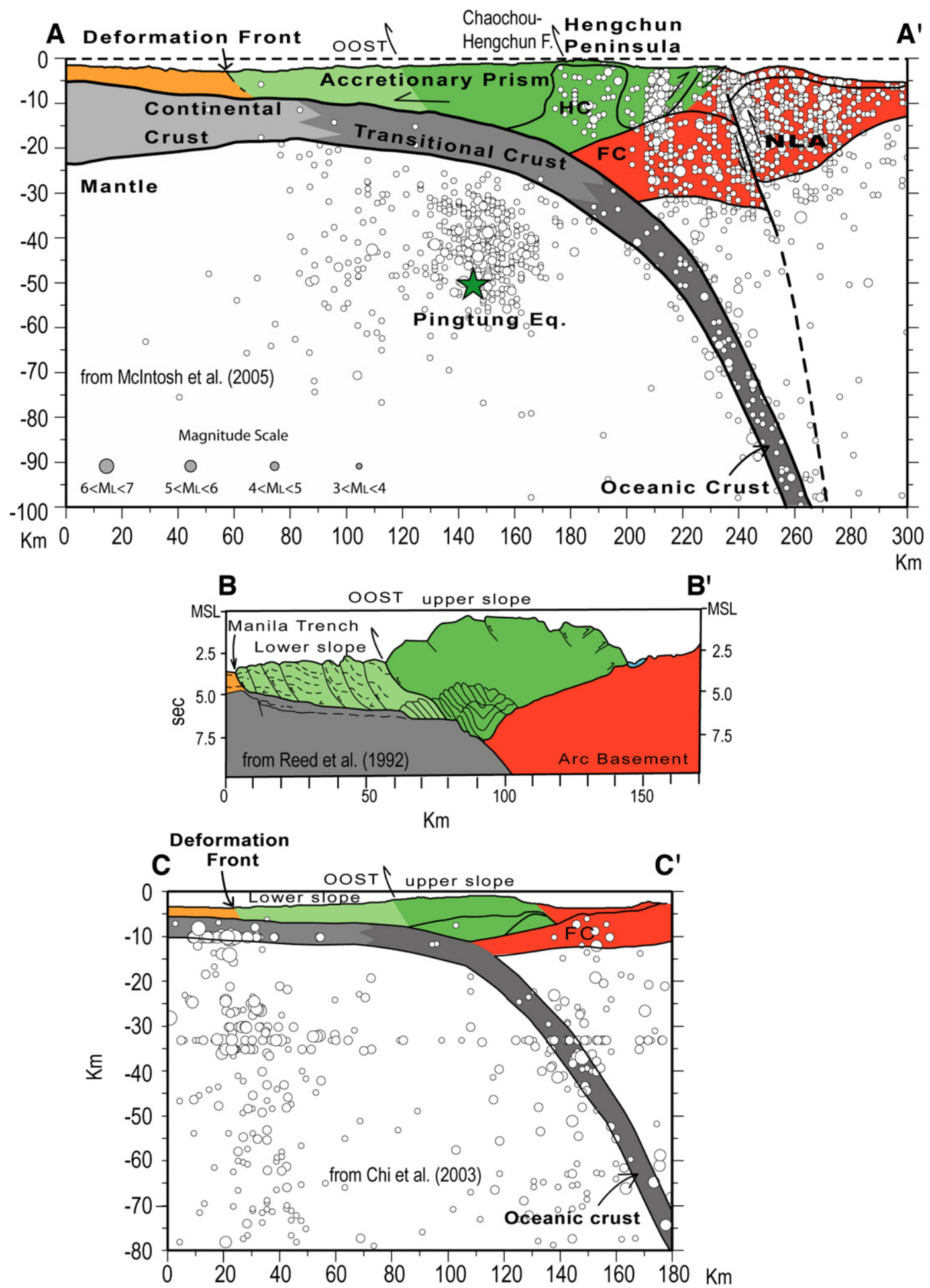

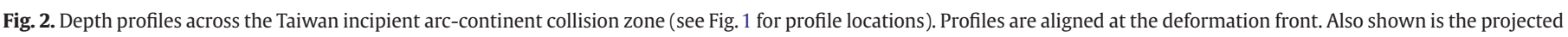

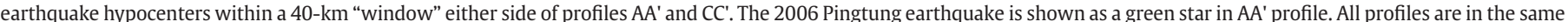

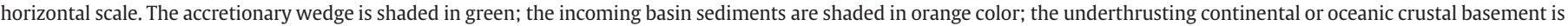

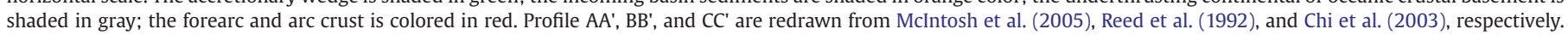
FC: Forearc Crust, HC: Hengchun Core, NLA: North Luzon Arc, OOST: Out-of-sequence thrust. 


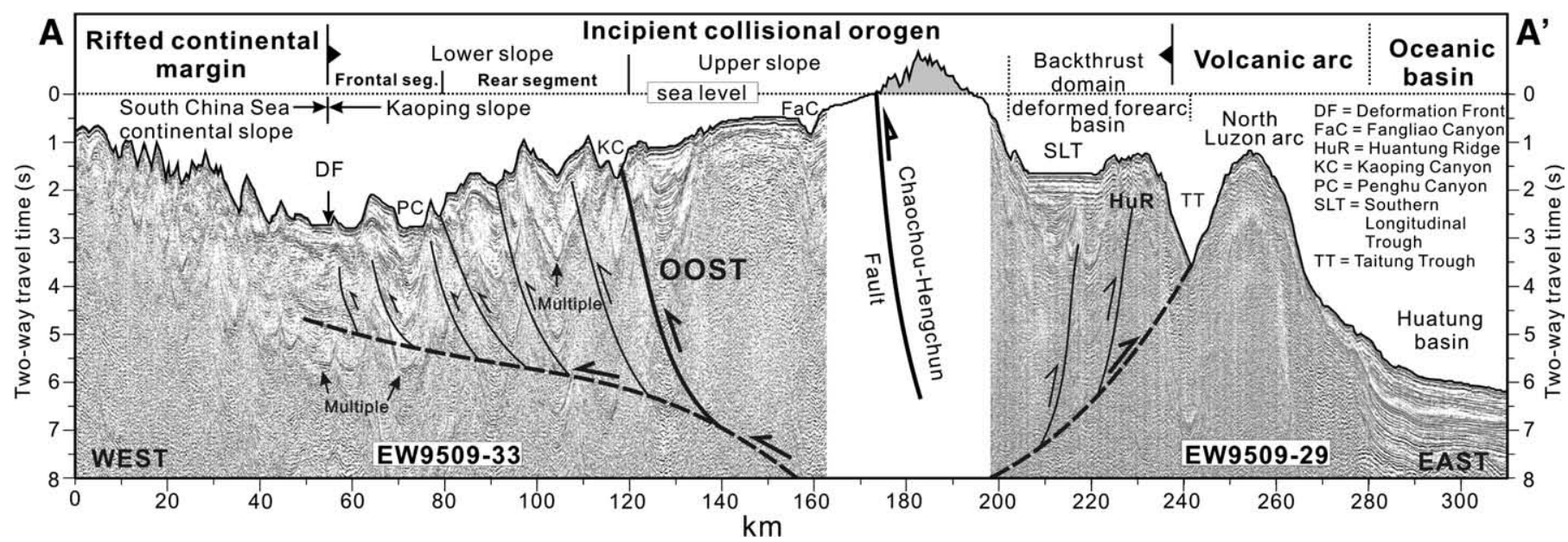

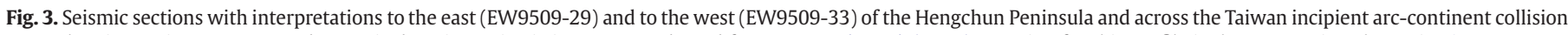
zone, showing major structure and tectonic domains. Seismic images are adapted from McIntosh et al. (2005). Location for this profile is the AA" section shown in Fig. 1.

We start by describing major geological features in the incipient arc-continent collision zone with an emphasis on major structural features found on seismic profile Line 973. We then contrast the structural styles along-strike for the accretionary wedge. We show that appreciable amounts of volcanics have been subducted, at least, beneath and along part of the frontal accretionary wedge. Finally, we discuss the implications for the seismogenic potentials as inferred from the tectonic features summarized above.

\section{Geological framework and seismicity pattern}

The areas of offshore and onshore southern Taiwan are in an initial stage of arc-continent collision (Huang et al., 1997, Fig. 1), which consists of the overriding collisional/accretionary complex and the underthrusting Eurasian lithosphere separated by the Manila trench and deformation front. West of the deformation front/Manila trench lies the northeastern corner of the South China Sea. There is still a debate as to where the continent-ocean transition occurs in the northeast corner of the South China Sea. Briais et al. (1993), for instance, put the continent-ocean transition south of around $20.5^{\circ} \mathrm{N}$ (i.e. $\mathrm{COT}_{1}$ shown in Fig. 1). Recent studies (e.g., Hsu et al., 2004) showed that the oceanic crust may extend further northward to $21.5^{\circ} \mathrm{N}$ and to the west of the NW-trending Luzon-Ryukyu Transform Plate Boundary (LRTPB). Their newly identified continent-ocean transition is shown as a dashed line and labeled $\mathrm{COT}_{2}$ in the inset figure of Fig. 1. Some authors (i.e., Hsu and Sibuet, 1995; Sibuet and Hsu, 1997, 2004) suggested that the lineament, LRTPB, is a left-lateral transform fault connecting the former Manila trench in the south and the former Ryukyu trench in the north. The LRTPB may cease to be active since $\sim 20 \mathrm{Ma}$ (Hsu et al., 2004). In this sense, the crust lying to the east of the LRTPB and to the west of the deformation front is a piece of oceanic crust (Sibuet et al., 2002). Despite the controversy on the nature of the crust in the northeastern corner of the South China Sea, we assume that it is thinned Eurasian continental lithosphere that is subducting beneath the Luzon volcanic arc of the Philippine Sea plate in the incipient collision zone.

In the accretionary wedge and south of $21.5^{\circ} \mathrm{N}$, plate convergence is mostly accommodated by the intra-oceanic subduction of the oceanic lithosphere of the South China Sea beneath the Luzon arc with a $55^{\circ}$ and east-dipping Wadati-Benioff zone (Kao et al., 2000). North of $21.5^{\circ} \mathrm{N}$ from offshore SW Taiwan to southern Taiwan, by contrast, the Eurasian plate is buoyant continental lithosphere that resists subduction, and a significant fraction of plate convergence is accommodated by intense compressional deformation of the crust rather than by subduction of one plate beneath the other. Therefore, the accretionary wedge widens from $\sim 80 \mathrm{~km}$ in the south $\left(\sim 20.5^{\circ} \mathrm{N}\right)$ to $\sim 180 \mathrm{~km}$ near the southern tip of Taiwan (Fig. 1). In southern Taiwan, it marks the onset of full-scale arc-continent collision (Huang et al., 1997). Northwardly, the advanced arc-continent collision is manifested by the accretion of the Luzon arc onto the Eurasian margin, which forms the Coastal Range in eastern Taiwan.

Fig. 2 shows two depth sections (AA' and $\mathrm{CC}^{\prime}$ ) and one time section (BB') across the accretionary wedge and volcanic arc with projected earthquake hypocenters, revealing major tectonic features and seismicity in the study area. The seismic images of the upper crustal structures across AA' section is shown in Fig. 3. We will use this section, Fig. 3, to illustrate and describe the main tectonic features in the incipient arc-continent collision zone. In this zone, it consists of four geological provinces (Fig. 3). From the west to the east, they are: (1) the rifted continental margin (i.e., the South China Sea continental slope) lying to the west of the deformation front; (2) the incipient collisional orogen, a two-sided orogen, bounded by significant zones of thrusting on the west and on the east; (3) the Luzon volcanic arc, consisting of Pliocene to Pleistocene (Yang et al., 1995) volcanic arc massif; and (4) the oceanic basin (Huatung basin) lying on top of oceanic crust of the Philippine Sea plate.

The incipient collisional orogen is further divided into tectonic domains of lower slope, upper slope, and backthrust, respectively (Reed et al., 1992). Both the lower and upper-slope domains consist of offscraped China continental margin strata and orogenic detritus derived from Taiwan (Reed et al., 1992; Liu et al., 1997). Reed et al. (1992) suggested that the boundary between the domains of lower slope and upper slope marks the onset of significant upper wedge uplift due to out-of-sequence thrusting within the wedge and/or sediment underplating along the base of the wedge (see BB' section of Fig. 2). The backthrust domain lies in the eastern margin of the accretionary wedge and consists mostly of east-directed thrust faults (Reed et al., 1992; Lundberg et al., 1997; Chi et al., 2003). The backthrust domain in the south is a narrow zone characterized by tectonic wedging and upturned and east-dipping forearc basin strata (Reed

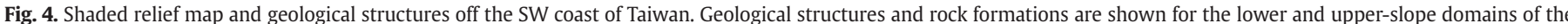

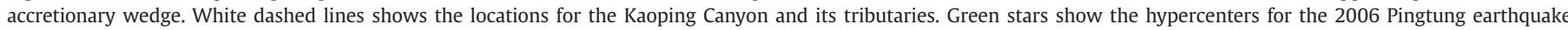

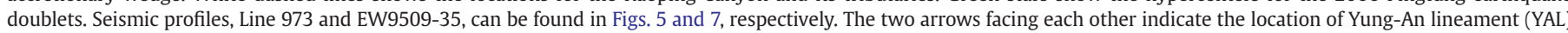
suggested by Liu et al. (2004). Explanations for acronyms can be found in Fig. 1. 


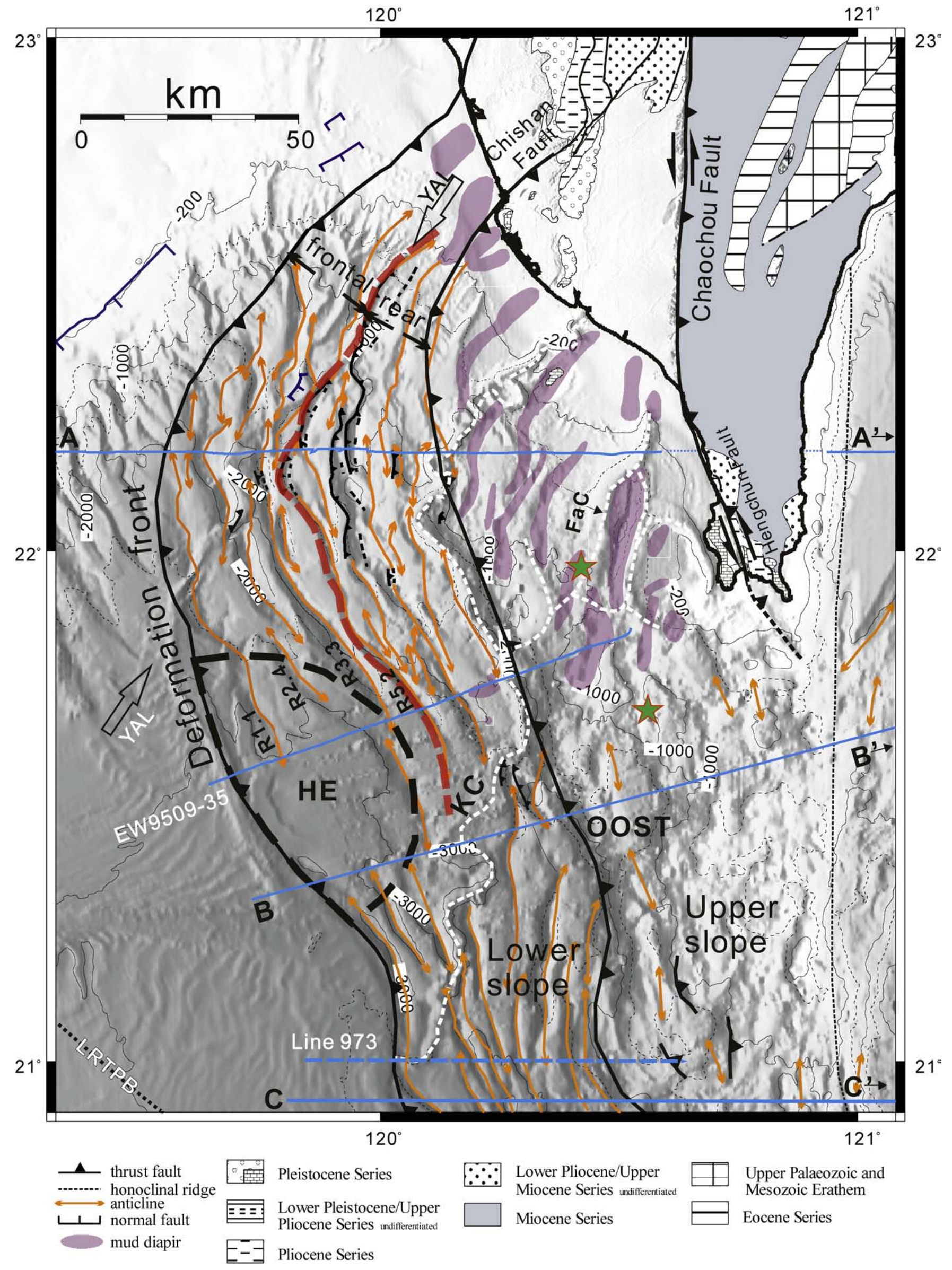


et al., 1992; Chi et al., 2003; Ding et al., 2006). Farther north near Taiwan, the backthrust domain is a fragmented forearc basin comprising the Southern Longitudinal Trough (Huang et al., 1992; Lundberg et al., 1997) and the Huatung Ridge because of the juxtaposition of the rear of the wedge and the volcanic arc in the incipient collision zone. The North Luzon Trough, a forearc basin, remains undeformed in the subduction segment in the south and it shows a westward thickening sequence that reaches a maximum thickness of $>3.5 \mathrm{~s}$ (two-way travel time) near the accretionary wedge (Reed et al., 1992).

The transition from oceanic subduction in the south (south of $\sim 21.5^{\circ} \mathrm{N}$ ) to arc-continent collision in the north is reflected in the seismicity pattern, especially beneath the arc and forearc areas. Figs. 1 and 2 show the earthquake hypocenters extracted from two earthquake catalogues of (1) the Central Weather Bureau Seismic Network (north of $21^{\circ} \mathrm{N}, M_{\mathrm{L}}>3$ and during the period of January 1991 to April 2007), and (2) the Incorporated Research Institutions for Seismology (IRIS, south of $21^{\circ} \mathrm{N}, M>3$ and during the period of February 1993 to August 2007). In the subduction domain (i.e. south of $21^{\circ} \mathrm{N}$ ), the earthquake hypocenters are largely sub-crustal and probably related to the Wadati-Benioff zone beneath the Luzon arc and forearc areas as suggested by Kao et al. (2000). Earthquake focal mechanisms are typical of subduction systems (Kao et al., 2000) with normal-faulting earthquakes near the trench axis, low-angle thrust events likely originated from seismogenic portion of the plate interface, and a dipping Wadati-Benioff zone further downdip. There is a significant scatter on hypocentral depths (from the IRIS database) beneath the accretionary wedge in the subduction segment, however, probably due to inaccurate focal depth determinations.

In the incipient arc-continent collision zone in between $\sim 21.5^{\circ} \mathrm{N}$ $\sim 23^{\circ} \mathrm{N}$, earthquakes that reside in the arc and forearc crust occurred more frequently (see Figs. 1 and 2), reflecting that plate convergence there, is partly accommodated by the deformation of forearc and arc crust. Indeed, two large and shallow historical earthquakes (Fig. 1) of magnitude $M_{\mathrm{w}} 7.0$ (1978) and $M_{\mathrm{L}} 7.1$ (1959) off the east coast of the Hengchun Peninsula show that the forearc area poses a great threat for seismic and, perhaps, tsunami hazards. Kao and Jian (2001) showed that crustal seismicity ( $<25 \mathrm{~km}$ depth) in the forearc areas are thrust or oblique-thrust faulting, consistent with the crustal thrusts observed from seismic imaging in the closing forearc basin (Lundberg et al., 1997).

There is a suggestion in Figs. 1 and 2 that, beneath the offshore accretionary wedge off SW Taiwan, earthquakes are largely subcrustal with the accretionary wedge being largely aseismic. Only in the southern tip of Taiwan and to the east of the Chaochou and Hengchun faults, the orogenic wedge exhibits seismicity, probably related to the rigid crustal material, marked as Hengchun core (HC) by McIntosh et al. (2005) and shown in AA' section of Fig. 2. The centroids of the 2006 Pingtung earthquake doublets occurred in a depth around $\sim 44 \sim 50 \mathrm{~km}$ (AA' section of Fig. 2), which is apparently residing in the mantle according to the crustal structure suggested by McIntosh et al. (2005). The 2006 Pingtung earthquakes occurred in the region of preexisting high level of seismic activity.

\section{Structures in the accretionary wedge}

The accretionary wedge in the incipient arc-continent collision zone of Taiwan consists of three structural belts, exhibiting distinct structural styles: the lower-slope domain, the upper-slope domain, and the backthrust domain (Reed et al., 1992). Here, we present a brief description of the structures of the lower and upper-slope domains, respectively.

\subsection{Lower-slope domain}

The lower-slope domain is a few tens of kilometers in width bounded in the west by the deformation front and in the east by out-of-sequence thrusts. This structural belt is characterized by a series of folds and imbricate thrust faults. A recently acquired multichannel seismic profile across the accretionary wedge (Line 973, Fig. 5), which locates near and along $21^{\circ} \mathrm{N}$ (Fig. 4), illustrates a clear decollement surface beneath the lower-slope domain, separating the accreted sediments above and underthrust oceanic sediments below. This seismic profile was collected onboard $R / V$ Tanbao of the Guangzhou Marine Geological Survey by a research consortium supported by Chinese Basic Research Priorities Program (People's Republic of China) in 2001, using a 240-channel of 12.5- $\mathrm{m}$ channel spacing and 3000-m long streamer. The seismic source was two arrays of air guns with a total volume of $3000 \mathrm{in}^{3}$ and was fired at 50-m interval. Its source-receiver configuration yielded a $\sim 30$-fold common depth point coverage.

This seismic profile can also be found in Ding et al. (2006), Deng et al. (2006), and Li et al. (2007). Published interpretations for this profile failed to recognize some structural features in the accretionary wedge, such as the underthrust sediment package, the frontal decollement, the out-of-sequence thrusts, and megathrust (see below), for example. We therefore re-interpret this seismic section with an emphasis on the aforementioned major tectonic features.

This migrated seismic image (Fig. 5) shows $\sim 1.3 \mathrm{~s}$ two-way travel time (TWT) thick sediments entering the subduction zone. Approximate $0.3 \mathrm{~s}$ (TWT) sediments subduct beneath the accretionary wedge, and the rest of sediments have been accreted by folding and thrusting above a subhorizontal decollement (hereafter named frontal decollement). The frontal decollement is a relatively continuous, subhorizontal and arcward-dipping strong reflection, lying 2-2.5 s (TWT) beneath the seafloor. The apparent upward convexity of the frontal decollement beneath $~ 7400-7600$ shot points may be due to the effect of velocity pull-up caused by a higher velocity of accreted sediments lying above the decollement. There is also a general correlation of bathymetry and this arcuate decollement interval, suggesting that it is related to velocity heterogeneity of its overlying materials. Above this strong reflection, reflectors reveal the accreted sediments showing varying degrees of folding, faulting and reduced seismic coherence with a few reverse faults branching upward from the decollement. The high amplitude of this strong reflection, a characteristic seismic feature of a frontal decollement in accretionary wedges (e.g., Bangs et al., 2004), may be due to the pronounced physical contrast, probably due to high pore pressure, of this surface and its host sediments. This strong reflection is analogous to the decollement surface imaged/cored at the Nankai Trough (Moore et al., 1990, 2001), Barbados (Bangs et al., 1990; Shipley et al., 1994), and Costa Rica (Tobin et al., 2001) accretionary wedges.

Beneath the frontal decollement, it is a $0.3 \mathrm{~s}$ (TWT) thick underthrust sediment section, overlying volcaniclastics and oceanic (?) basement (see below). The underthrust sediments show relatively seismically coherent and lower amplitude with little stratigraphic disruption. Similar seismic facies is found at the lowest stratigraphic section of the incoming basin sediments in front of the deformation front (i.e., 5.5-5.8 s [TWT] beneath shot points 6500-6600 in Fig. 5). The seismic characteristics indicate that the subducted sediments are probably of homogeneous, fine-grained and hemipelagic basin facies, similar to those observed and cored at the Nankai Trough (Moore et al., 2001). This packet of seismic reflectors is bounded at its base by a series of discontinuous and strong reflectors. Judging from the existence of the buried volcanic seamounts near the oceanic (?) basement and beneath the vicinity of deformation front, we interpret the series of high amplitude reflectors as volcaniclastic aprons that fringe the buried seamounts (volcanoclastics of similar seismic facies on top of oceanic basement were drilled at the Nankai Trough, Moore et al., 2001).

The frontal decollement in the accretionary wedge is a mechanical boundary that may separate domains which have different structural styles. For example, Lallemant et al. (1993) and Morgan and Karig (1995) documented, in other accretionary wedges, a compressive 

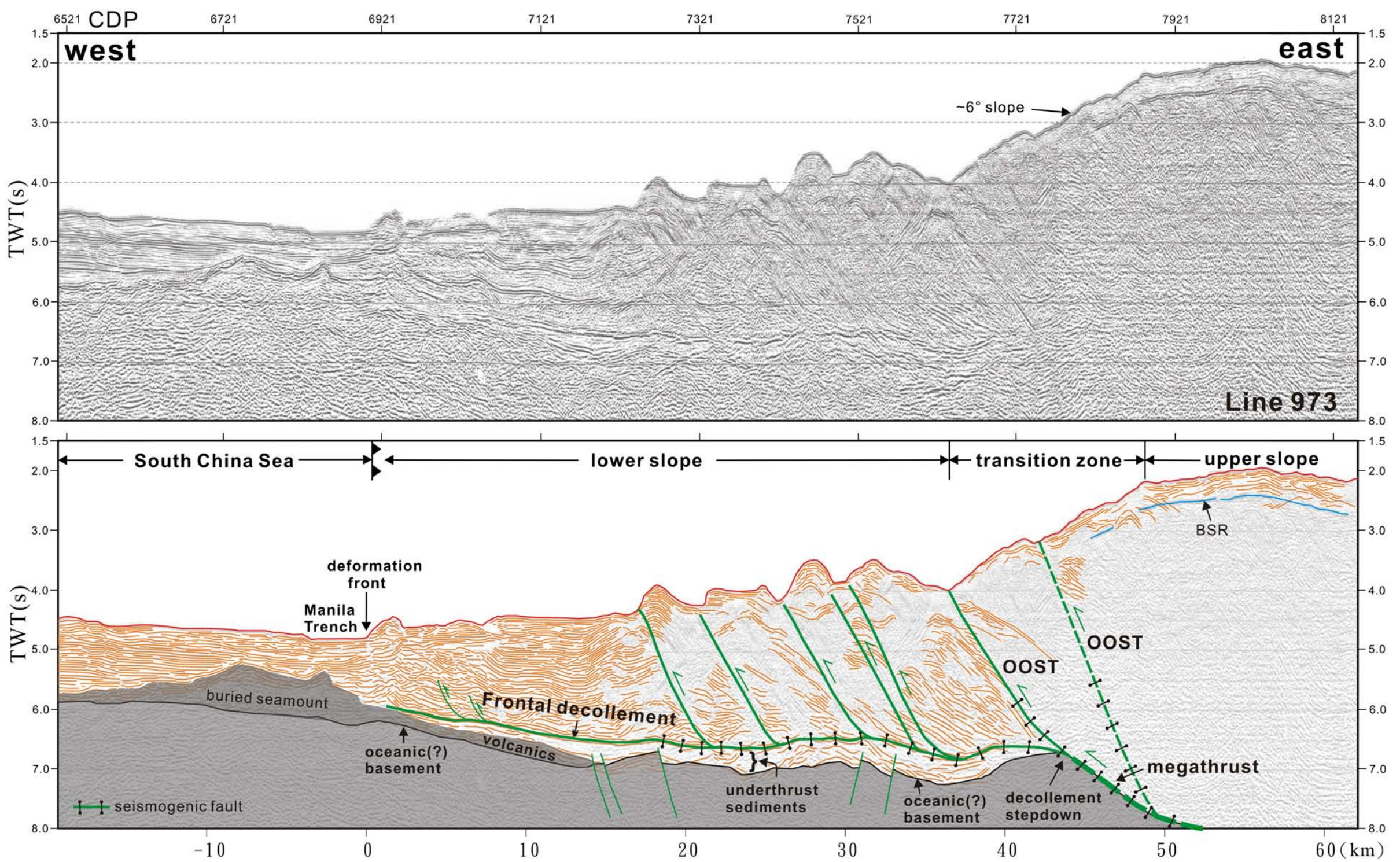

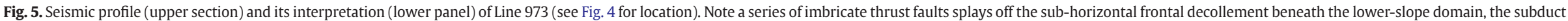

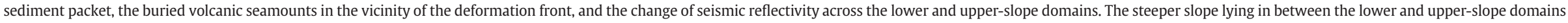
is defined as a transition zone and is interpreted to riddle with an array of out-of-sequence thrusts that sole into the plate-boundary megathrust beneath the lower slope. CDP: common depth points. 
stress state above the decollement in the accreted sediments and an extensional stress state below the decollement surface in a subducted sediment section. The contrast of stress state across the frontal decollement may therefore result in different structural styles with compressional features developed above the decollement and extensional structures beneath it. Fig. 5 shows such a case where the normal faults beneath the frontal decollement may develop in response to the inferred tensile stress state beneath the decollement. An alternative explanation for the normal faults beneath the decollement is that the normal faulting may develop prior to the basin sediments entering into the accretionary wedge. Indeed, $\mathrm{Ku}$ and $\mathrm{Hsu}$ (in press) documented normal faults cluster especially in front of the deformation front and along the Manila trench due, probably, to plate bending of the subducting slab. Near this seismic profile (along $21^{\circ} \mathrm{N}$ ) and beneath the frontal decollement of the lower-slope domain, Kao et al. (2000) resolved 5 moderate-sized earthquakes of normal-faulting events, consistent with observations from seismic imaging mentioned above.

The width of the lower-slope domain increases northwardly from $\sim 50 \mathrm{~km}$ in the south to up to $70 \mathrm{~km}$ in the north (Fig. 4). The deformation front swings toward the west when the accretionary wedge impinges obliquely onto the rifted continental margin-slope in the north. The widening of the lower slope domain is accompanied by wider thrust/fold spacing in the north (Fig. 4). Lin et al. (2008) interpreted that the westward swing of the deformation front results from the northward thickening of the underthrust sediments. They further divided the lower-slope domain off SW Taiwan into frontal and rear segments, respectively (Fig. 4), with frontal segment dominated by folds cored by blind thrusts, and rear segment by thrusts breaching the seafloor. Where the accretionary wedge impinges upon the continental slope, the folds terminate successively against the continental slope, leading to the deformation front swinging back to the east and narrowing of the width of the lower-slope domain. This deformed unit connects to the outer fold-and-thrust belt of the onshore Western Foothills of Taiwan. Liu et al. (2004) suggested a dextral strike-slip fault termed Yung-An Lineament (YAL in Fig. 4) to accommodate the southwestward expulsion of the structural belt of SW Taiwan.

\subsection{Hengchun embayment (a wide proto-thrust zone)}

In the lower slope domain of the accretionary wedge, there is a scallop-shaped embayment (Figs. 4, 6, 7), showing little or no fold/ thrust structures coupled by smooth seafloor topography with gentle seaward-dipping slope. We herein coin this embayment as Hengchun embayment because it is near the Hengchun peninsula. This embayment is bordered to the north and south by fold-and-thrust belts within the accretionary wedge. In the northern fringe of the Hengchun embayment, there is a consistent southward plunge of structural belts (Fig. 4), leading to the decrease of fold amplitudes and thus ridge heights successively across the northern boundary of this embayment. Similarly, along the southern fringe of the embayment, the folds/ thrusts, south of the embayment, plunge northward upon approaching the embayment. It is noted that the strike of fold does not curve to accommodate the curvature of the embayment both in the northern and southern fringe of the embayment.

Fig. 7 is a seismic section adapted from Lin et al. (2008) traversing the northern part of the embayment. The seismic section shows that the embayment is a zone of subdued relief with little compressional deformation and diffuse structural thickening. For example, near the deformation front, structures of R1.1, R2.4, and R3.3 as reported in Lin et al. (in press) exhibit a gentle uplift with incipient development of fold structures (Fig. 7). The first major compressional structure is R5.2 belt, which is $\sim 40 \mathrm{~km}$ landward from the deformation front. The tectonic feature is similar to the proto-thrust zone seen in other accretionary prism (e.g., the Nankai Trough, Moore et al., 1990). The width of the proto-thrust zone (a few tens-of-km wide) as outlined by the Hengchun embayment (Fig. 6) is far wider than that in other accretionary prism (generally $<10 \mathrm{~km}$ wide, such as in the Nankai [Moore et al., 1990] and Cascadian [Cochrane et al., 1994] prisms). Indeed, Ku and $\mathrm{Hsu}$ (in press) has delineated and recognized the protothrust zone to the south of the Hengchun embayment, and its width is also generally less than $10 \mathrm{~km}$ wide. The unusual greater width of the Hengchun embayment is therefore an anomalous feature and deserves to pay more attention to this geological feature.

Fig. 7 demonstrates that at around $7 \mathrm{~s}$ in depth and beneath 35005500 CDPs, it exhibits irregular, rough, rubbly appearance, and high amplitude reflections, indicative of basement reflections. A seismic tie between the intersecting seismic sections of EW9509-35 and EW9509-45 (see their locations in Fig. 6) clarifies that the top rubbly reflections seen beneath the Hengchun embayment are top-ofvolcanics. Overlying the basement is a sediment pile, $\sim 2-3 \mathrm{~s}$ (TWT) thick, which thickens in an arcward direction. At the base of this sediment pile, sediments progressively onlap onto the landwarddipping, rubbly basement surface with $\sim 0.8 \mathrm{~s}$ (TWT) vertical relief.

Along the seismic profile, EW9509-45 (Sibuet et al., 2002), which runs approximately parallel to the deformation front, shows that sediments thin toward and onlap onto a peaked volcanic body centered at $119^{\circ} 47^{\prime} \mathrm{E}, 21^{\circ} 15^{\prime} \mathrm{N}$ (marked as filled blue triangle in Fig. 6). This volcanic body is up to $\sim 2 \mathrm{~s}$ (TWT) thick beneath the distal slope (see Fig. 6 for the spatial distribution of this volcanic body along this seismic profile). Seismic images reveal that an appreciable amount of volcanics have been subducted, at least, beneath the lower-slope domain, and volcanic seamounts, buried beneath the incoming basin sediments, are about to be subducted or accreted in the accretionary wedge. We carried out an inversion of magnetic anomalies to derive the equivalent crustal magnetization in order to map out possible distribution of the buried volcanics. The magnetic anomalies are from Hsu et al. (1998), and the magnetic inversion assumes that the magnetic anomalies originate from an equivalent layer of constant thickness of $6 \mathrm{~km}$. Fig. 6 shows our results of crustal magnetization with red shading indicating higher magnetization, corresponding to the possible existence of buried volcanic materials. The area of high magnetization covers a large part of the South China Sea basin, south of the Formosa Canyon. Similar results were found by Yeh and Hsu (2004), and Ku and Hsu (in press) from seismic imaging. Part of the lower-slope domain also underlies by high magnetization crustal material. Available seismic images (e.g., EW9509-35, EW9509-45, and Line 973 reported here and other ACT lines shown in Sibuet et al., 2002) show volcanic materials or seamount features corresponding to the high magnetization zone. Besides, the seamount feature at $119^{\circ} 13^{\prime} \mathrm{E}, 21^{\circ} 08^{\prime} \mathrm{N}$ (Fig. 6) lies in the high magnetization area, consistent with our results from magnetic inversions. All these features indicate that the high magnetization area possibly corresponds to area with thick volcanic materials.

Similar topographic feature like the Hengchun embayment can be found elsewhere, for example, the Tosabae embayment (Yamazaki and Okamura, 1989) of the Nankai Trough. We note that the Tosabae embayment lies in front of the deformation front instead of lying within the accretionary wedge and arcward of the deformation front. Gulick et al. (2004) invoked the accretion of seamount to explain the origin of the Tosabae embayment. By analogy with the Tosabae embayment noted above, one may therefore speculate that the Hengchun embayment is resulted from the subduction of buried volcanic seamounts as evidenced from the existence of volcanic materials beneath the Hengchun embayment (Fig. 7) and inferred from the results of magnetic inversion (Fig. 6) as shown above. However, there is, perhaps, a problem for this speculation. South of the Hengchun embayment and near the course of the Kaoping Canyon, a series of fold-and-thrust develops there (Fig. 4), but the lower-slope domain is also underlain by subducted volcanic materials as imaged by seismic profiling and inferred from magnetic inversion (Fig. 6). Similar subduction of volcanic materials results in contrasting responses, however: one of them demonstrates 


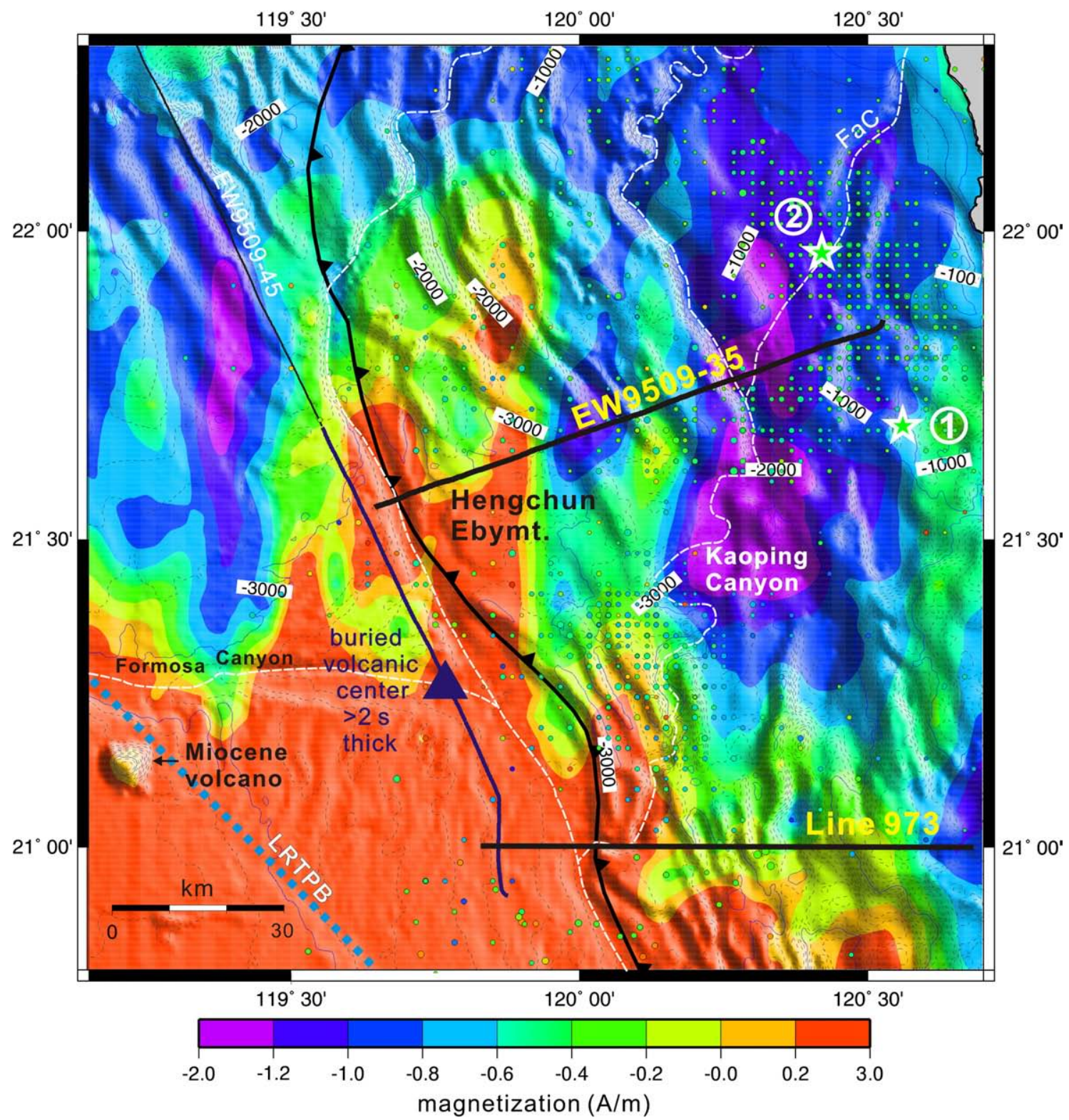

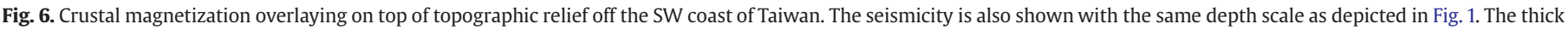

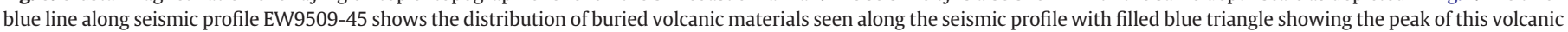

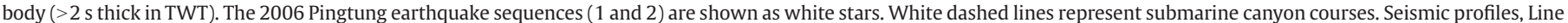
973 and EW9509-35 can be found in Figs. 5 and 7, respectively. Numbers mark the bathymetry for every 1000 m. FaC: Fangliao Canyon.

smooth topography as shown in the Hengchun embayment, and the other one with rugged topography caused by folding and thrusting near the drainage of the Kaoping Canyon. Apparently, while the model of seamount accretion is feasible in the case of Tosabae embayment of the Nankai Trough, it may fail to explain the Hengchun embayment in the study area. Therefore a different explanation for the origin of the Hengchun embayment is needed.

Wang et al. (1994) suggested that the magnitude of pore pressure within the incipient decollement may control the width of the protothrust zone. The magnitude of pore pressure is determined by the amount of water expelled from the sediments in the accretionary wedge. The area of Hengchun embayment coincides with the depositional site of a paleo-submarine fan of the Kaoping Canyon (Liu et al., 1993; Chiang and Yu, 2006) and thick subducted sediments. Thick sequence of subducted and accreted sediments results as more fluid to be expelled from the compacted sediments. The expelled fluids may flow from places of higher pressure to that of lower pressure and they tend to channelize through major fault zones, such as the frontal decollement (Tobin et al., 2001). Therefore it creates an elevated pore pressure in the fault zones, leading to a decrease of the shear strength of the faults and wall rocks by deceasing effective normal stress (Moore and Vrolijk, 1992). Higher pore pressures on the incipient decollement would lead to a broader proto-thrust zone and less deformation as suggested by Cello and Nurr (1988) and Wang et al. (1994). In this sense, we interpret that the Hengchun embayment to result from a mild deformation due to high pore pressure in this area. The existence of the local Hengchun embayment and inferred local high pore pressure indicate that pore pressures on incipient decollement vary along-strike owing to the variations in the amount of subducted and accreted sediments.

\subsection{Upper-slope domain}

The upper-slope domain is characterized by reduced seismic reflections (Figs. 3, 5, 7), probably due to more steeply-dipping beds because of intense tectonic deformation. Unlike the seafloor topography 


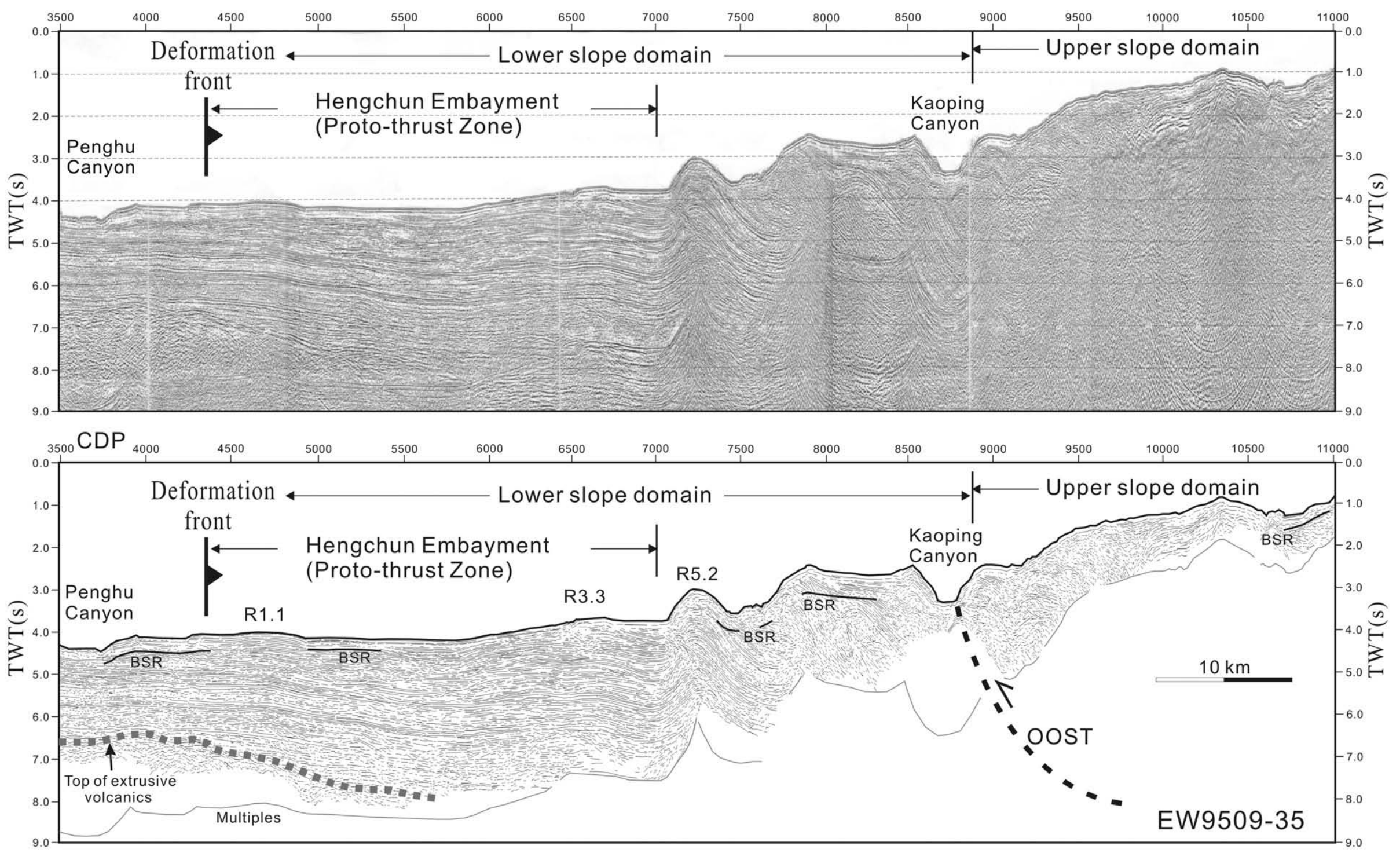

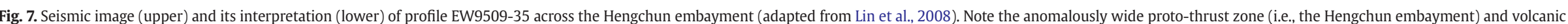
body buried beneath the vicinity of the deformation front and the Hengchun embayment. BSR: Bottom simulating reflectors. 
of the lower-slope domain, which is characterized by a series of bathymetric ridges related to active thrusting and folding, the seafloor of the upper-slope domain shows more smoothed topography, indicating that most of faults in this domain have been inactive. However, active deformation in the upper-slope domain is more localized, such as along the boundary between the lower and upper-slope domains as well as along a few diapiric ridges near the SW coast of Taiwan (discussed below).

The tectonic domains of lower slope and upper slope are separated by a prominent morphologic break, probably related to the onset of out-of-sequence thrusting in the upper-slope domain first proposed by Reed et al. (1992). As reported in the Nankai accretionary prism of Japan (e.g., Moore et al., 2001, 2007; Bangs et al., 2006), similar morphologic break, that separates the frontal and rear wedge, is riddled with multiple out-of-sequence thrusts (OOSTs) or termed splay faults, and megasplay faults by various authors (e.g., Park et al., 2002; Moore et al., 2007), capable of generating great earthquakes (Park et al., 2002). Accordingly, possible faulting beneath the morphologic break in the transition zone (Fig. 5) requires further investigations especially for seismic threats.

The newly acquired seismic profile, Line 973, reported in this paper, provides us with a better subsurface image and hence warrants us to elaborate more on the significance of the OOSTs in the study area. From the bathymetric map and the seismic image of Line 973 (Fig. 5), one finds the following observations: (1) the wedge taper increases dramatically in the transition zone (i.e., the morphologic break), (2) the reflectors of the frontal decollement, underthrust sediments, and top of oceanic (?) basement beneath the lower slope domain, disappear beneath the transition zone and beyond, (3) there is a significant change of seismic reflectivity across the OOSTs. In the footwall of the fault (i.e., the lower-slope domain), wedge material exhibits well defined seismic reflectors; whereas in the hanging wall of the fault (i.e., the upper-slope domain), it is generally characterized by chaotic reflections without major stratal seismic reflections.

The increase of wedge taper in the transition zone indicates that active structures may underlie the transition zone. The active nature of faults beneath the transition zone is also evidenced by the tilted and arcward-dipping strata of recent sediments in the upper slope (not shown in Fig. 5 but can be found in Fig. 3 of Ding et al., 2006). The change of seismic reflectivity across the transition zone implies a major mechanical discontinuity of the wedge material beneath the transition zone. Although no faults are visible due to poor seismic imaging, it is highly likely that there is an array of active out-ofsequence thrusts lying beneath the morphologic break similar to the frontal "large thrust slice zone" of the Nankai Trough described by Moore et al. (2001, 2007).

Bangs et al. (2004) have shown that, in the Nankai Trough, the decrease of seismic amplitude of the frontal decollement coincides with (1) an increase of wedge taper, (2) the stepping down of the decollement to a deeper stratigraphic level, (3) thrust becoming seismogenic. Because the decollement reflection disappears beneath the transition zone as shown in Line 973 (Fig. 5), and the structural similarity observed in the study area and in the Nankai Trough (e.g., Moore et al., 2001, 2007; Park et al., 2002; Bangs et al., 2004), we interpret that the decollement steps down to the top of oceanic (?) basement beneath the transition zone. There are, of course, other alternatives for the geometry of the decollement beneath the upper slope due to poor seismic imaging there. For example, the decollement may produce duplex in the sedimentary cover as suggested by Reed et al. (1992) and shown schematically in profile BB' of Fig. 2.

We propose, from above arguments, that a large (or an array of) out-of-sequence thrust(s) branches upward from the master decollement about $40 \mathrm{~km}$ arcward from the trench and beneath the transition zone lying in between the lower and upper-slope domains. The frontal decollement steps down to top of oceanic (?) basement there and beyond, where we coin the master decollement as the megathrust
(Fig. 5) by analogy to similar structures of the Nankai accretionary prism (Park et al., 2002).

The existence of the zone riddled with an array of OOSTs between the lower and upper-slope domain is marked by a break in surface slope as mentioned above. The distinct slope break extends from $\sim 20.6^{\circ} \mathrm{N}$ to near the Taiwan island at $\sim 22^{\circ} \mathrm{N}$, arriving at the course of the Kaoping Canyon, for, at least, $150 \mathrm{~km}$ in length (the northern segment). The topographic contrast becomes subdued when this zone approaches the SW coast of Taiwan because of, perhaps, rapid sedimentation that levels out the topography. South of $\sim 20.5^{\circ} \mathrm{N}$, there is another slope break within the accretionary wedge, extending for some $\sim 100 \mathrm{~km}$ and arriving at $\sim 19.5^{\circ} \mathrm{N}$ (the southern segment). In between these two segments, it is marked by a topographic saddle lying at about $\sim 20.6-20.3^{\circ} \mathrm{N}$ and separating the north and south segments.

The width of the upper-slope domain widens northwardly from $\sim 30 \mathrm{~km}$ in the subduction segment to $\sim 90 \mathrm{~km}$ in the north, which incorporates the Hengchun Peninsula of southern Taiwan. The upperslope domain in the far north consists of two parts: (1) west of the Chaochou and Hengchun faults which is characterized by a series of mud diapirs off the SW coast (Sun and Liu, 1993). Some of these mud diapiric structures connect northwardly onshore to become thrust faults, and (2) east of Chaochou and Hengchun faults, which consisting of more rigid rocks (termed Hengchun core in Fig. 2). We first discuss the diapiric structures off SW coast of Taiwan and then address the tectonic significance of the Chaochou and Hengchun faults.

According to Lacombe et al. (2004), the mud diapirs off the SW coast initiated as thrust-related anticlines. Mud diapirism was later initiated by upward migration of fluids and fluid-saturated mud material, in response to deeper burial and differential sediment loading. Overpressured muds exhibit lower density when compared with normally pressured muds. The lower density of overpressured muds indicate that they tend to flow upward and be replaced by denser, normally compacted sediments from above, promoting the development of mud diapirs.

The link between the Chaochou fault and Hengchun fault is unclear. Some authors linked the Chaochou fault southward to the offshore along the length of the Fangliao Canyon (Liu et al., 1997), while others linked the Chaochou Fault to the Hengchun Fault in the southern tip of Taiwan (Ho, 1986). Here we adapt the later interpretation. Both Chaochou and Hengchun Faults are probable active faults (Lin et al., 2000), while Lu (1994) and Lacombe et al. (2001) suggested that the Chaochou fault is an active sinistral wrench fault. There is a sharp contrast of material strength across the Chaochou fault and its southern continuation (the Hengchun Fault). To the east of the Chaochou Fault, sediments are slightly metamorphosed (argillite or slate-grade of metamorphism) north of $\sim 22.2^{\circ} \mathrm{N}$; south of $\sim 22.2^{\circ} \mathrm{N}$, sediments are less metamorphosed but still well-compacted especially in the Miocene sediments. The nature of slightly metamorphosed and well-compacted rocks to the east of the faults is reflected as a high-velocity zone (i.e., Hengchun core) shown in the AA's section of Fig. 2 and suggested by McIntosh et al. (2005).

To the west of the Chaochou and Hengchun faults, sediments are loosely compacted. The sharp contrast in material strength across these faults indicates that there is a pronounced vertical stratigraphic offset across the faults. Along the Hengchun fault segment, rocks of oceanic-basement affinity are found on the hangingwall in the Kenting Melange (Tsan, 1974a). Early works (e.g., Tsan, 1974b; Page and Lan,1983) suggested that this stratigraphic unit is an olistostrome. However, other works (e.g., Pelletier and Stephan, 1986; Huang et al., 1997; Chang et al., 2003) interpreted that the Kengting Melange is a tectonic mélange. This indicates that the Hengchun fault cuts into the oceanic basement and part of the oceanic basement was peeled off and transported to the surface within the fault zone. Therefore it suggests that the Hengchun fault is an out-of-sequence thrust branching upward from, perhaps, the megathrust that resides in the oceanic basement. If the Hengchun fault is active as suggested by Lin 
et al. (2000), it may therefore pose a great seismic threat, similar to the OOSTs found on seismic profile Line 973 (Fig. 5).

\section{Seismicity of southern Taiwan and offshore}

Earthquakes in the collision zone may reside mostly in the crust (Maggi et al., 2000; Jackson, 2002) with only a few subcrustal shocks being observed (Chen and Molnar, 1983; Chen and Yang, 2004). By contrast, in subduction zones, earthquakes are occurring both in the overriding plate as well as in the subducted slab with deep earthquakes that may reach up to $\sim 690 \mathrm{~km}$ (Kirby et al., 1991). In the incipient arc-continent collision zone, such as in the study area, the seismic characteristics may therefore resemble that of both the collision zones as well as the subduction zones.

North of $\sim 23^{\circ} \mathrm{N}$ and beneath the Taiwan collisional orogen where full collision occurs, it shows seismicity mostly residing in the crust (Tsai, 1986) and without the Wadati-Benioff zone signature. By comparison, south of $\sim 21.5^{\circ} \mathrm{N}$, in the subduction segment, the seismicity reveals a $200 \mathrm{~km}$ deep and east-dipping Benioff zone with a dip angle of $\sim 55^{\circ}$ (Kao et al., 2000). In the incipient arc-continent collision zone (i.e., areas lying in between $\sim 21.5$ and $23^{\circ} \mathrm{N}$ ), crustal seismicity characterizes the forearc and arc regions, in addition to earthquakes related to the deeper Wadati-Benioff zone. Crustal seismicity in the accretionary wedge concentrates to the east of the ChaochouHengchun faults and in the backthrust domain, whereas largely no crustal seismicity is apparent to the west of the Chaochou-Hengchun fault.

It is interesting to note that, off SW Taiwan, most of the seismicity occurs not in the accreted accretionary wedge but in the upper mantle of the subducted slab, resembling the intra-slab subduction earthquakes as noted by Kirby et al. (1996). Most of the intra-slab subduction earthquake events lie in $~ 30-60 \mathrm{~km}$ depth range with some events extending to maximum depths of about $80 \mathrm{~km}$ if the focal depth determinations are correct. The main concentration of seismicity is in a band paralleling the NNW-striking middle reach of the Kaoping Canyon and decreasing in intensity to the north and to the south. Focal mechanisms near the trench and at $\sim 21^{\circ} \mathrm{N}$ are normal-faulting events (Kao et al., 2000). The hypocenters of the 2006 Pingtung earthquake doublets (both around $M_{\mathrm{b}} 7.0$ in magnitude, according to Central Weather Bureau, Taiwan) locate at a depth range of $\sim 44-50 \mathrm{~km}$, and they are probably the best examples of intra-slab subduction earthquakes in the study area. In addition to the earthquakes occurring in the subducting slab and accreted accretionary wedge, earthquakes may occur on the plate interfaces of subducting and overriding plates (i.e., along the frontal decollement/megathrust, and OOSTs). We note that, in the study area, there have been no historical records of major plate interface earthquakes recorded so far.

\section{Discussion}

\subsection{Intra-slab subduction earthquakes}

We first discuss why intra-slab subduction earthquakes that reside in the upper mantle are prone to occur off SW Taiwan. We then address the nature of low seismicity, according to the historical record, of the accreted accretionary wedge to the west of the ChaochouHengchun faults.

The occurrence of intra-slab subduction earthquakes in the mantle off the SW coast of Taiwan indicates that the subducted lithospheric mantle is strong enough to accumulate elastic strain. However, the frequent mantle earthquakes in the study area is an anomalous feature as the mantle in other orogenic systems is usually characterized by reduced earthquake occurrences (e.g., Chen and Molnar, 1983; Chen and Yang, 2004) or no seismicity as suggested by Jackson (2002). In order to explain the anomalously frequent occurrence of mantle earthquakes as well as its brittle nature, we envisage that the initially strong mantle off the SW coast of Taiwan may have been weakened by other processes before the upper mantle entered the subduction zone (see below). Then it tends to break and hence induces seismicity due to, perhaps, loading and flexing by orogenic loads.

It is widely believed that the temperature (Ranalli, 1995) and volatile contents (Hirth and Kohlstedt, 1996) of the lithospheric mantle significantly affect its strength. A hot and high volatile content lithospheric mantle exhibits low strength. Direct heat-flow measurements and BSR-derived heat flows in the lower-slope domain of the accretionary wedge off southern Taiwan (Shyu et al., 2006; Chi and Reed, 2008) show that the average heat flow there is around $60 \mathrm{~mW} \mathrm{~m}^{-2}$, a value which is higher than the global average $\left(\sim 45 \mathrm{~mW} \mathrm{~m}^{-2}\right)$ in other accretionary wedges in the vicinity of trench (Jessop, 1990). If we examine the heat flow in the foreland area, we find that the geothermal gradient measured from hydrocarbon exploration wells on the continental shelf (see the red circle labeled CFC in Fig. 1) is around $35^{\circ} \mathrm{C} / \mathrm{km}$ (Wu et al., 1993). Assuming a thermal conductivity of $2 \mathrm{Wm}^{-1}{ }^{\circ} \mathrm{C}^{-1}$ for the shale-prone drilled succession, estimated heat flow at CFC well is around $70 \mathrm{~mW} \mathrm{~m}^{-2}$. As foreland basins are characterized by low geothermal gradients (e.g., $22-24{ }^{\circ} \mathrm{C} / \mathrm{km}$ for North Alpine foreland basin, Allen and Allen, 2005, p.397) the high geothermal/heat flow value in the study area both in the incoming plate and in the accretionary wedge is therefore anomalous. We suggested that the high heat flow in the study area is due to the hotter-than-normal upper mantle. The hot subducting mantle is most likely due to the inheritance of (1) Mesozoic subduction event (Teng and Lin, 2004); (2) rifting events accompanied by magmatism during the Paleocene-Oligocene (Briais et al., 1993; Lin et al., 2003), 30-21 Ma, and 12.5 6.5 Ma (Lin et al., 2003).

During the Mesozoic subduction event, the China continental lithosphere was sitting on top of a west-dipping and subducting oceanic slab (Teng and Lin, 2004), allowing the possibility of trace amounts of volatiles derived from the oceanic slab to infiltrate the mantle wedge of the overlying continental lithosphere. The Mesozoic mantle wedge now becomes part of the east-dipping and subducting lithospheric mantle. The multiple episodes of Cenozoic rifting events as mentioned above indicate still hot lithosphere, because $80 \mathrm{Myr}$ is the approximate duration for continental lithosphere to regain thermal equilibrium after a thermal event (McKenzie, 1978).

\subsection{Nature of low seismic level in the accreted accretionary wedge off SW Taiwan}

The lack of earthquakes with magnitudes higher than 3 in the accretionary wedge off the SW coast Taiwan (e.g., Wu et al., 1997 and Figs. 1 and 2) indicates that the accreted orogenic material there is weak and being unable to sustain the accumulation of elastic strain needed for generating greater than small-sized earthquakes. We interpret that the weak rheology of the accreted material off the coast of SW Taiwan is due to thick and rapid mud accumulation and the existence of high pore pressures in the wedge based on the following arguments.

Shale ridges and mud diapirs characterize the upper-slope domain off the SW coast of Taiwan, indicating the existence of overpressured shale. Rieke and Chilingarian (1974) suggested that factors of (1) high initial pore water content, (2) low permeability and large thickness of overburden, (3) deeper burial depth, and (4) short time allowed for dewatering, contribute to form intervals of overpressured shale. Off SW Taiwan and near the coast, the mud sequence is at least a few $\mathrm{km}$ in thickness, and is rapidly deposited (Huh et al., in press) and therefore buried, resulting in overpressured shale that promotes ductile mud flowage and hence mud diapirism.

Because of the thick accreted and underthrust sediments near Taiwan, a large amount of water has been expelled from the compacted sediments in the accretionary wedge, leading to channelized flows and high pore pressures especially along major fault zones and 
porous beds. As noted above, high pore pressure results in the wedge material being unable to sustain large shear stress. Vigorous fluid expulsion, a sign of the existence of high pore-pressure zones, in the offshore accretionary belt is also attested by: (1) widespread occurrence of bottom simulating reflectors (BSRs, Liu et al., 2006; Lin et al., submitted for publication), indicating the presence of gas hydrates and thus sufficient supply of methane and water, (2) the existence of an array of mud volcanoes (Chiu et al., 2006; Liu et al., 2006), (3) mud diapirism in the upper slope (Sun and Liu, 1993), (4) high methane content in seafloor sediments (Chuang et al., 2006), (5) chemosynthetic biological communities in deep water.

\subsection{Frontal decollement, out-of-sequence thrusts and megathrust}

We have shown that the major tectonic features in the Taiwan incipient collisional wedge are: (1) frontal decollement beneath the lower-slope domain, (2) out-of-sequence thrusts bordering the lowerslope and upper-slope domains, (3) megathrust that cuts into the oceanic (?) basement beneath the upper-slope domain, and (4) the Chaochou-Hengchun faults in the onshore upper-slope domain. We discuss, in this section, the seismogenesis for the above tectonic features.

The seismogenic zone is defined as earthquake generating rupture fault zone (Byrne et al., 1988). Hyndman et al. (1995, 1997) suggested that there is a general correlation of thermal regime and the extent of seismogenic zone in the subduction regime. They suggested that the updip limit of the seismogenic zone coincides with $150{ }^{\circ} \mathrm{C}$ isotherm, and the downdip limit corresponds to $350-450{ }^{\circ} \mathrm{C}$ isotherm. Here we use the thermal regime to discuss the seismogenic potentials for the frontal decollement, out-of-sequence thrusts and the megathrust in the study area.

We have shown that the frontal decollement stepdown occurs at about 3-4 s (TWT) beneath the topographic break of the lower and upper slope domain (i.e., the transition zone), and the transition zone is probably riddled with an array of out-of-sequence thrusts. In order to convert the TWT of seismic line 973 into depth, we need to know the velocity along this profile. About $10 \mathrm{~km}$ south of this profile (i.e., along $20.9^{\circ} \mathrm{N}$ ), Chi et al. (2003) derived a crustal density model constrained by gravity anomaly and seismic imaging. They showed that the upper-slope domain consists of a rock body of $2.42 \mathrm{~g} \mathrm{~cm}^{3}$ of density in average. The density-velocity relation can then be derived by using the Gardner's equation (Gardner et al., 1974), and it yields an average seismic velocity of $\sim 3700 \mathrm{~m} / \mathrm{s}$ for the upper-slope domain. The depth of frontal decollement stepdown (i.e., around $3-4$ s TWT) is accordingly estimated to be around $\sim 5.5-7.4 \mathrm{~km}$ beneath the seafloor. We assume that the temperature gradient beneath the transition zone is around $\sim 38{ }^{\circ} \mathrm{C} / \mathrm{km}$ according to a sediment heat-probe measurement (Shyu et al., 2006) from a nearby site $\left(120.5535^{\circ} \mathrm{E}, 21.5184^{\circ} \mathrm{N}\right)$ at the same tectonic zone. Similar value of the thermal gradient there was also suggested by Chi and Reed (2008). With the assumed thermal gradient, the temperature of the top decollement stepdown seen along Line 973 profile (Fig. 5) is therefore estimated to be around $\sim 210-280{ }^{\circ} \mathrm{C}$.

As the estimated temperature of the portion of frontal-decollement stepdown is around $\sim 210-280^{\circ} \mathrm{C}$, which is above the lower threshold temperature (i.e., $150{ }^{\circ} \mathrm{C}$ as noted above) for a seismogenic zone. This simple calculation indicates that interplate coupling occurs in the frontal decollement stepdown beneath the transition zone and beyond (i.e., along the megathrust), suggesting the seismogenic nature of the megathrust. Similar calculations can be applied to the frontal decollement in the lower-slope domain. We use the average rock density of $2.3 \mathrm{~g} \mathrm{~cm}^{3}$ for the lower-slope domain (Chi et al., 2003), which is equivalent to a seismic velocity of $\sim 3000 \mathrm{~m} / \mathrm{s}$ according to the Gardner's equation. If the thermal gradient is of $\sim 38^{\circ} \mathrm{C} / \mathrm{km}$ (Shyu et al., 2006), the updip limit of the seismogenic zone (i.e., $150^{\circ} \mathrm{C}$ ) lies $\sim 2.6 \mathrm{~s}$ (TWT) beneath the seafloor. If these inferences are correct, the frontal decollement in the rear of the lower-slope domain is seismogenic, while the trenchward part is a steadily slipping subduction fault and hence aseismic (Fig. 5). Even if the trenchward part of the frontal decollement is aseismic, rupture in the downdip seismogenic zone has shown to propagate to the trench during large and great earthquakes (Seno, 2000), resulting in a sudden uplift of the weak accretionary prism of the lower-slope domain and may therefore generate tsunamis. Our inference does not indicate that the thrust faults branching upward from the frontal decollement in the lower-slope domain are all aseismic faults. Some of them, especially in the rear part of the lower-slope domain, may be seismogenic as their expected temperatures are probably higher than $150^{\circ} \mathrm{C}$.

Judging from the lack of prominent historical seismicity as shown in Figs. 1 and 2 within the accreted sediments of lower and upper-slope domains, one may conclude that the aforementioned frontal decollement, OOSTs, and megathrust are of less seismic threats. We caution that the above major structures may be during interseismic locking stage and hence no major seismic activity is recorded there. Taking the December 2004 Sumatra earthquake for example, Lay et al. (2005) and Engdahl et al. (2007) noted that, prior to the great earthquake, seismicity occurred downdip along the interplate zone at depths greater than $35 \mathrm{~km}$, with a quasi-absence of seismicity trenchward.

We conclude that the OOSTs and plate boundary megathrust found in the study area are similar to those found in the Nankai Trough (Park et al., 2002, Moore et al., 2007). By analogy with the (mega) splay fault and megathrust of the Nankai accretionary prisms (Park et al., 2002, Moore et al., 2007), we infer that the OOSTs (equivalent to megasplay faults of the Nankai prism) and the megathrust reported here are capable of generating great earthquakes (i.e., $M>8$ ). As such, these faults pose great seismic and tsunami threat to the populations of Taiwan and its neighboring regions similar to cases of 1944 Tonankai $(M=8.1$, Ichinose et al., 2003) and 1946 Nanakai $(M=8.3$, Baba et al., 2002), tsunamigenic earthquakes of the Nankai accretionary prism. We call for more future investigations on the frontal decollement, OOSTs, and megathrust to understand their seismogenic and tsunamignenic potential.

Teng et al. (2005) pointed out that the onshore Chishan fault, Chaochou fault and Hengchun fault are three notable OOSTs, among others, in the upper slope domain. Lin et al. (2008) showed that the OOST, bordering the lower and upper-slope domain, connects to the onshore Shoushan fault and further north to the Chishan fault (Fig. 1). If this is correct, the offshore OOSTs extend further onshore and it therefore poses great seismic threat to this region.

\section{Conclusions}

In the incipient Taiwan arc-continent collision zone, the accretionary wedge widens from south to north in response to the subduction of less dense continental lithosphere toward the north. Prominent tectonic structures in the accretionary wedge include: (1) frontal decollement beneath the lower-slope domain, (2) out-ofsequence thrusts bordering the lower-slope and upper-slope domains, (3) megathrust that cuts into the oceanic (?) basement beneath the upper-slope domain, and (4) the Chaochou-Hengchun faults in the onshore upper-slope domain. These structures and the internal deformations of the accretionary wedge change along-strike because of the variations of (a) the amount of incoming basin sediments and sediments deposited in the accretionary wedge, (b) subducted seamounts beneath, at least, the lower-slope domain, and (c) pore pressures. Seamount subduction has a potentially significant impact on wedge deformation and stress permutation that may generate asperities for great subduction-zone earthquakes. High pore pressure leads in a local, scallop-shaped proto-thrust zone in the frontal accretionary wedge, coined Hengchun embayment in the present study. Near Taiwan, high pore pressure also results in the mud flowage and mud diapirism and therefore less seismicity in the accreted wedge. 
We conclude that shallow seismicity (shallower than tens of $\mathrm{km}$ ) in the incipient arc-continent collision zone of Taiwan may fall into four categories: (1) intra-slab earthquakes that reside in the subducting mantle off SW Taiwan; (2) crustal earthquakes in the deformed forearc and arc regions; (3) earthquake clusters that occur to the east of the Chaochou-Hengchun fault in more rigid orogenic wedge; (4) plateinterface and its associated faults (i.e., frontal decollement, out-ofsequence thrusts and megathrust) within the accretionary wedge. The former two categories occur more frequently than the rest, and the second category may be more destructive as it is of shallower origin. The last category is subduction thrust earthquakes occurring repeatedly in most subduction zones and it poses, perhaps, the greatest seismic and tsunami hazards as it is capable of generating great earthquakes by analogy to other accretionary prisms.

Our results highlight the needs for investigating the seismogenic and tsunamigenic potentials for a few important structures in the accretionary wedge of the Taiwan incipient collision zone. Among them, the out-of-sequence thrusts lying in between the lower and upper-slope domains, the plate-boundary megathrust lying beneath the upper-slope domain, the onshore Chaochou-Hengchun fault system need special attention.

\section{Acknowledgements}

Dr. Sibuet, J.-C and the other anonymous reviewer are thanked for their valuable comments and suggestions. We thank the crew members of the $R / V$ Tanbao for their efforts on collecting Line 973 seismic data. Wei-Zhi Liao and Che-Chuan Lin helped drawing some of the figures. F. Mouthereau read the first draft and gave valuable comments that have greatly improved the manuscript. This research has been supported through the grants partly from National Science Council, R.O.C. (NSC962627M008-001) and Central Geological Survey, Ministry of Economics Affairs, R.O.C. (96-5226903000-01-01) to A.T. Lin, and grant G2000046705 from the National Important Basic Research and Development Projects of People's Republic of China to B. Yao. This is an IGCP 524 publication.

\section{References}

Allen, P.A., Allen, J.R., 2005. Basin Analysis: Principles and Applications, (2nd edition). Blackwell Publishing. 549 pp.

Baba, T., Tanioka, Y., Cummins, P.R., Uhira, K., 2002. The slip distribution of the 1946 Nankai earthquake estimated from tsunami inversion using a new plate model. Physics of the Earth and Planetary Interiors 132, 59-73.

Bangs, N.L.B., Westbrook, G.K., Ladd, J.W., Buhl, P., 1990. Seismic velocities from the Barbados Ridge complex: indicators of high pore fluid pressures in an accretionary complex. Journal of Geophysical Research 95, 8767-8782.

Bangs, N.L.B., Shipley, T.H., Gulick, S.P.S., Moore, G.F., Kuromoto, S., Nakamura, Y., 2004. Evolution of the Nankai Trough décollement from the trench into the seismogenic zone: Inferences from three-dimensional seismic reflection imaging. Geology 32, 273-276.

Bangs, N.L.B., Gulick, S.P.S., Shipley, T.H., 2006. Seamount subduction erosion in the Nankai Trough and its potential impact on the seismogenic zone. Geology 34, 701-704.

Bilek, S.L., Lay, T., 1999. Rigidity variations with depth along interplate megathrust faults in subduction zones. Nature 400, 443-446.

Briais, A., Patriat, P., Tapponnier, P., 1993. Updated interpretation of magnetic anomalies and sea-floor spreading stages in the South China Sea: Implications or the Tertiary tectonics of Southeast Asia. Journal of Geophysical Research 98, 6299-6328.

Byrne, D.E., Davis, D.M., Sykes, L.R., 1988. Loci and maximum size of thrust earthquakes and the mechanics of the shallow region of subduction zones. Tectonics 7 , 833-857.

Cello, G., Nurr, A., 1988. Emplacement of foreland thrust systems. Tectonics 7, 261-272.

Chang, C.-P., Angelier, J., Lee, T.-Q., Huang, C.-Y., 2003. From continental margin extension to collision orogen: structural development and tectonic rotation of the Hengchun peninsula, southern Taiwan. Tectonophysics 361, 61-82.

Chen, W.-P., Molnar, P., 1983. Focal depths of intracontinental and intraplate earthquakes and their implications for the thermal and mechanical properties of the lithosphere. Journal of Geophysical Research 88, 4183-4214.

Chen, W.-P., Yang, Z., 2004. Earthquakes beneath the Himalayas and Tibet: evidence for strong lithospheric mantle. Science 304, 1949-1952.

Chi, W.-C., Reed, D.L., 2008. Evolution of shallow, crustal thermal structure from subduction to collision: An example from Taiwan. Geological Society of America Bulletin 120, 679-690.
Chi, W.-C., Reed, D.L., Moore, G., Nguyen, T., Liu, C.-S., Lundberg, N., 2003. Tectonic wedging along the rear of the offshore Taiwan accretionary prism. Tectonophysics 374, 199-217.

Chiang, C.-S., Yu, H.-S., 2006. Morphotectonics and incision of the Kaoping submarine canyon, SW Taiwan orogenic wedge. Geomorphology 80, 199-213.

Chiu, J.-K., Tseng, W.-H., Liu, C.-S., 2006. Distribution of gassy sediments and mud volcanoes offshore southwestern Taiwan. Terrestrial, Atmospheric and Oceanic Sciences 17, 703-722.

Chuang, P.-C., Yang, T.F., Lin, S., Lee, H.-F., Lan, T.-F., Hong, W.-L., Liu, C.-S., Chen, J.-C., Wang, Y., 2006. Extremely high methane concentration in bottom water and cored sediments from offshore southwestern Taiwan. Terrestrial, Atmospheric and Oceanic Sciences 17, 903-920.

Cochrane, G.R., Moore, J.C., MacKay, M.E., Moore, G.F., 1994. Velocity and inferred porosity model of the Oregon accretionary prism from multichannel seismic reflection data: Implications on sediment dewatering and overpressure. Journal of Geophysical Research 99, 7033-7043.

Deng, H., Yan, P., Liu, H., Luo, W., 2006. Seismic data processing and the characterization of a gas hydrate bearing zone offshore of southwestern Taiwan. Terrestrial, Atmospheric and Oceanic Sciences 17, 781-797.

Ding, W., Yang, S., Chen, H., Cheng, X., Wu, N., 2006. Arc-continent collision orogeny in offshore Taiwan during Neogene. Chinese Journal of Geology 41, 195-201 (in Chinese).

Engdahl, E.R. Villaseñor, A., DeShon, H.R. Thurber C.H., 2007. Teleseismic relocation and assessment of seismicity (1918-2005) in the region of the $2004 M_{w} 9.0$ Sumatra-Andaman and $2005 M_{\mathrm{w}} 8.6$ Nias Island great earthquakes. Bulletin of the Seismological Society of America 97, 43-61.

Gardner, G.H.F., Gardner, L.W., Gregory, A.R., 1974. Formation velocity and density - the diagnostic basics for stratigraphic traps. Geophysics 39, 770-780.

Gulick, S.P.S., Bangs, N.L.B., Shipley, T.H., Nakamura, Y., Moore, G., Kuramoto, S., 2004. Threedimensional architecture of the Nankai accretionary prism's imbricate thrust zone off Cape Muroto, Japan: prism reconstruction via en echelon thrust propagation. Journal of Geophysical Research 109, B02105. doi:10.1029/2003JB002654.

Hirth, G., Kohlstedt, D.L., 1996. Water in the oceanic upper mantle: Implications for rheology, melt extraction and the evolution of the lithosphere. Earth and Planetary Science Letters 144, 93-108.

Ho, C.-S., 1986. A synthesis of the geologic evolution of Taiwan. Tectonophysics 125 $1-16$

Hsu, S.-K., Sibuet, J.-C., 1995. Is Taiwan the result of arc-continent or arc-arc collision? Earth Planetary Science Letters 136, 315-324.

Hsu, S.-K., Liu, C.-S., Shyu, C.-T., Liu, S.-Y., Sibuet, J.-C., Lallemand, S., Wang, C.-S., Reed, D.L., 1998. New gravity and magnetic anomaly maps in the Taiwan-Luzon region and their preliminary interpretation. Terrestrial, Atmospheric and Oceanic Sciences 9, 509-532.

Hsu, S.-K., Yeh, Y.-C., Doo, W.-B., Tsai, C.-H., 2004. New bathymetry and magnetic lineations identifications in the northernmost South China Sea and their tectonic implications. Marine Geophysical Researches 25, 29-44.

Huh, C.-A., Lin, H.-L., Lin, S., Huang, Y.-W., (in press). Modern accumulation rates and a budget of sediment off the Kaoping River, SW Taiwan: A tidal and flood dominated depositional environment around a submarine canyon. Journal of Marine Systems, doi:10.1016/j.jmarsys.2007.07.009.

Huang, C.-Y., Shyu, C.-T., Lin, S.-B., Lee, T.-Q., Sheu, D.-D., 1992. Marine geology in the arccontinent collision zone off southeastern Taiwan: implications for late Neogene evolution of the Coastal Range. Marine Geology 107, 183-212.

Huang, C.-Y., Wu, W.-Y., Chang, C.-P., Tsao, S., Yuan, P.B., Lin, C.-W., Xia, K.-Y., 1997. Tectonic evolution of accretionary prism in the arc-continent collision terrane of Taiwan. Tectonophysics 281, 31-51.

Huang, S.-T., Yang, K.-M., Hung, J.-H., Wu, J.-C., Ting, H.-H., Mei, W.-W., Hsu, S.-H., Lee M., 2004. Deformation front development at the northeast margin of the Tainan basin, Tainan-Kaohsiung area, Taiwan. Marine Geophysical Researches 25, 139-156.

Hyndman, R.D., Wang, K., Yamano, M., 1995. Thermal constraints on the seismogenic portion of the southwestern Japan subduction thrust. Journal of Geophysical Research 100, 15373-15392.

Hyndman, R.D., Yamano, M., Oleskevich, D.A., 1997. The seismogenic zone of subduction thrust faults. The Island Arc 6, 244-260.

Ichinose, G.A., Thio, H.K., Somerville, P.G., Sato, T., Ishii, T., 2003. Rupture process of the 1944 Tonankai earthquake $\left(\mathrm{M}_{\mathrm{s}} 8.1\right)$ from the inversion of teleseismic and regional seismograms. Journal of Geophysical Research 108, 2497. doi:10.1029/2003JB002393.

Jackson, J., 2002. Strength of the continental lithosphere: time to abandon the jelly sandwich? GSA Today 12, 4-10

Jessop, A.M., 1990. Developments in Solid Earth Geophysics. Thermal Geophysics, vol. 17. Elsevier, Amsterdam.

Kao, H., Jian, P.-R., 2001. Seismogenic patterns in the Taiwan region: insights from source parameter inversion of BATS data. Tectonophysics 333, 179-198.

Kao, H., Huang, G.-C., Liu, C.-S., 2000. Transition from oblique subduction to collision in the northern Luzon arc-Taiwan region: constraints from bathymetry and seismic observations. Journal of Geophysical Research 105, 3059-3079.

Kirby, S.H., Durham, W.B., Stern, L.A., 1991. Mantle phase changes and deep-earthquake faulting in subducting lithosphere. Science 252, 216-225.

Kirby, S.H., Engdahl, E.R., Denlinger, R., 1996. Intermediate-depth intraslab earthquakes and arc volcanism as physical expressions of crustal and uppermost mantle metamorphism in subducting slabs. In: Bebout, G., Scholl, D., Kirby, S., Platt, J. (Eds.) Subduction: Top to Bottom. Geophysical Monograph 96. American Geophysical Union, pp. 195-214.

Ku, C.-Y., Hsu, S.-K., (in press). Crustal structure and deformation at the northern $\}$ Manila Trench between Taiwan and Luzon islands. Tectonophysics. doi:10.1016/j. tecto.2007.11.012. 
Lacombe, O., Mouthereau, F., Angelier, J., Deffontaines, B., 2001. Structural, geodetic and seismological evidence for tectonic escape in SW Taiwan. Tectonophysics 333, 323-345.

Lacombe, O., Angelier, J., Mouthereau, F., Chu, H.-T., Deffontaines, B., Lee, J.-C., Rocher, M. Chen, R.-F., Siame, L., 2004. The Liuchiu Hsu island offshore SW Taiwan: tectonic versus diapiric anticline development and comparisons with onshore structures. Comptes Rendus Geosciences 336, 815-825.

Lallemant, S.J., Byrne, T., Maltman, A., Karig, D.E., Henry, P., 1993. Stress tensors at the toe of the Nankai accretionary prism: an application of inverse methods slickenlined faults. Proceedings Ocean Drilling Program Scientific Results, Part B 131, 103-122.

Lay, T., Kanamori, H., Ammon, C.J., Nettles, M., Ward, S.N., Aster, R.C., Beck, S.L., Bilek, S.L. Brudzinski, M.R., Butler, R., DeShon, H.R., Ekstrm, G., Satake, K., Sipkin, S., 2005. The great Sumatra-Andaman earthquake of 26 December 2004. Science 308, $1127-1133$.

Li, C.-F, Zhou, Z., Li, J., Hao, H., Geng J., 2007. Structures of the northeasternmost South China Sea continental margin and ocean basin: geophysical constraints and tectonic implications. Marine Geophysical Researches 28, 59-79.

Lin, C.-W., Chang, H.-C., Lu, S.-T., Shih, T.-S., Huang, W.-J., 2000. An introduction to the active faults of Taiwan: explanatory text of the active fault map of Taiwan, scale 1:500,000. Special Publication Central Geological Survey 13 122pp. (in Chinese)

Lin, A.T., Watts, A.B., Hesselbo, S.P., 2003. Cenozoic stratigraphy and subsidence history of the South China Sea margin in the Taiwan region. Basin Research 15, 453-478.

Lin, A.T. , Liu, C.-S., Lin, C.-C., Schnurle, P., Chen, G.-Y., Liao, W.-Z., Chuang, H.-R., Teng, L.S. $\mathrm{Wu}, \mathrm{M}-\mathrm{S} .2008$. Tectonic features associated with the overriding of an accretionary wedge on top of a rifted continental margin: An example from Taiwan. Marine Geology 255, 186-203. doi:10.1016/j.margeo.2008.10.002.

Lin, C.-C., Lin, A.T., Liu, C.-S., Schnurle, P., Chen, G.-Y., Liao, W.-Z., (submitted for publication). Geological controls on BSR occurrences in the incipient arc-continent collision zone offshore southwest Taiwan. Marine and Petroleum Geology. doi:10.1016/j.marpetgeo.2008.11.002.

Liu, C.-S., Lundberg, N., Reed, D., Huang, I.-L., 1993. Morphological and seismic characteristics of the Kaoping submarine canyon. Marine Geology 111, 93-108.

Liu, C.-S., Huang, I.-L., Teng, L.S., 1997. Structural features off southwestern Taiwan. Marine Geology 137, 305-319.

Liu, C.-S., Liu, S.-Y., Lallemand, S., Lundberg, N., Reed, D.L., 1998. Digital elevation mode offshore Taiwan and its tectonic implication. Terrestrial, Atmospheric and Oceanic Sciences 9, 705-738.

Liu, C.-S., Deffontaines, B., Lu, C.-Y., Lallemand, S., 2004. Deformation patterns of an accretionary wedge in the transition zone from subduction to collision offshore southwestern Taiwan. Marine Geophysical Research 25, 123-137.

Liu, C.-S., Schn rle, P., Wang, Y., Chung, S.-H., Chen, S.-C., Hsiuan, T.-H., 2006 Distribution and characters of gas hydrate offshore of southwestern Taiwan. Terrestrial, Atmospheric and Oceanic Sciences 17, 615-644.

Lu, C.-Y., 1994. Neotectonics in the foreland thrust belt of Taiwan. Petroleum Geology of Taiwan 29, 1-26.

Lundberg, N., Reed, D.L., Liu, C.-S., Lieske Jr., J., 1997. Forearc-basin closure and arc accretion in the submarine suture zone south of Taiwan. Tectonophysics 274, 5-23.

Maggi, A., Jackson, J.A., McKenzie, D., Priestley, K., 2000. Earthquake focal depths, effective elastic thickness, and the strength of the continental lithosphere. Geology 28, 495-498.

McIntosh, K., Nakamura, Y., Wang, T.-K., Shih, R.-C., Chen, A., Liu, C.-S., 2005. Crustalscale seismic profiles across Taiwan and the western Philippine Sea. Tectonophysics 401, 23-54.

McKenzie, D.P., 1978. Some remarks on the development of sedimentary basins. Earth Planetary Science Letters 40, 25-32.

Moore, J.C., Vrolijk, P., 1992. Fluids in accretionary prisms. Reviews of Geophysics 30, $113-135$

Moore, G.F., Shipley, T.H., Stoffa, P.L., Karig, D.E., Taira, A., Kuramoto, S., Tokuyama, H., Suyehiro, K., 1990. Structure of the Nankai Trough accretionary zone from multichannel seismic reflection data. Journal of Geophysical Research 95, 8753-8765.

Moore, G.F., Taira, A., Klaus, A., Becker, L., Boeckel, B., Cragg, B.A., Dean, A., Fergusson, C.L., Henry, P., Hirano, S., Hisamitsu, T., Hunze, S., Kastner, M., Maltman, A.J., Morgan, J.K., Murakami, Y., Saffer, D.M., Sanchez-Gomez, M., Screaton, E.J., Smith, D.C., Spivack, A.J., Steurer, J., Tobin, H.J., Ujiie, K., Underwood, M.B., Wilson, M., 2001. New insights into deformation and fluid flow processes in the Nankai Trough accretionary prism: results of Ocean Drilling Program Leg 190. Geochemistry, Geophysics and Geosystems 2 2001GC000166.

Moore, G.F., Bangs, N.L., Taira, A., Kuramoto, S., Pangborn, E., Tobin, H.J., 2007. Threedimensional splay fault geometry and implications for tsunami generation. Science $318,1128-1131$
Morgan, J.K., Karig, D.E., 1995. Decollement processes at the Nankai accretionary margin, southeast Japan: propagation, deformation, and dewatering. Journal of Geophysical Research 100, 15221-15231.

Nakamura, Y., McIntosh, K., Chen, A.T., 1998. Preliminary results of a large offset seismic survey west of Hengchun Peninsula, Southern Taiwan. Terrestrial, Atmospheric and Oceanic Sciences 9, 395-408.

Page, B.M., Lan, C.-Y., 1983. The Kenting Melange and its record of tectonic events. Memoir of the Geological Society of China 5, 227-248.

Park, J.-O., Tsuru, T., Kodaira, S., Cummins, P.R., Kaneda, Y., 2002. Splay fault branching along the Nankai subduction zone. Science 297, 1157-1160.

Pelletier, B., Stephan, J.F., 1986. Middle Miocene obduction and late Miocene beginning of collision registered in the Hengchun Peninsula: geodynamic implications for the evolution of Taiwan. Tectonophysics 125, 133-160.

Ranalli, G., 1995. Rheology of the Earth, (2nd edition). Chapman Hall. 413 pp.

Reed, D.L., Lundberg, N., Liu, C.-S., Kuo, B.-Y., 1992. Structural relations along the margins of the offshore Taiwan accretionary wedge: implications for accretion and crustal kinematics. Acta Geologica Taiwanica 30, 105-122.

Rieke, H.H., Chilingarian, G.V., 1974. Compaction of Argillaceous Sediments. Elsevier, Amsterdam.

Seno, T., 2000. The 21 September, 1999 Chi-Chi earthquake in Taiwan: implications for tsunami earthquakes. Terrestrial, Atmospheric and Oceanic Sciences 11, 701-708.

Shipley, T.H., Moore, G.F., Bangs, N.L. Moore, J.C. Stoffa, P.L., 1994. Seismically inferred dilatancy distribution, northern Barbados Ridge decollement: implications for fluid migration and fault strength. Geology 22, 411-414.

Shyu, J.B.H., Sieh, K., Chen, Y.-G., Liu, C.-S., 2005. Neotectonic architecture of Taiwan and its implications for future large earthquakes. Journal of Geophysical Research 110. doi:10.1029/2004JB003251.

Shyu, C.-T., Chen, Y.-J., Chiang, S.-T., Liu, C.-S., 2006. Heat flow measurements over bottom simulating reflectors, offshore southwestern Taiwan. Terrestrial, Atmospheric and Oceanic Sciences 17, 845-869.

Sibuet, J.-C., Hsu, S.-K., 1997. Geodynamics of the Taiwan arc-arc collision. Tectonophysics $274,221-251$.

Sibuet, J.-C., Hsu, S.-K., 2004. How was Taiwan created? Tectonophysics 379, 159-186

Sibuet, J.C., Hsu, S.-K., Le Pichon, X., Le Formal, J.P., Reed, D.L., Moore, G., Liu, C.-S., 2002. East Asia plate tectonics since $15 \mathrm{Ma}$ : constraints from the Taiwan region. Tectonophysics 344, 103-134.

Sun, S.-C., Liu, C.-S., 1993. Mud diapirs and submarine channel deposits in offshore Kaohsiung-Hengchun, southwest Taiwan. Petroleum Geology of Taiwan 28, 1-14.

Teng, L.S., Lin, A.T., 2004. Cenozoic tectonics of the China continental margin: Insights from Taiwan. In: Malpas, J., Fletcher, C.J. Aitchinson, J.C. Ali, J. (Eds.), Aspects of the Tectonic Evolution of China. Geological Society, 226. Special Publications, London, pp. 313-332.

Teng, L.S., Rau, R.-J., Lee, C.-T., Liu, C.-S., Chen, W.-S., 2005. Faulting in southwestern Taiwan. Western Pacific Earth Sciences 5, 97-128 (in Chinese).

Tobin, H., P., Vannucchi, P., Meschede, M., 2001. Structure, inferred mechanical properties, and implications for fluid transport in the decollement zone, Costa Rica convergent margin. Geology 29, 907-910.

Tsai, Y.-B., 1986. Seismotectonics of Taiwan. Tectonophysics 125, 17-37.

Tsan, S.-F., 1974a. The Kenting Formation: a note of Hengchun peninsula stratigraphy. Proceedings Geological Society China 17,131-134.

Tsan, S.-F., 1974b. Stratigraphy and structure of the Hengchun peninsula, with special reference to a Miocene olistostrome. Bulletin Geological Survey Taiwan 24, 99-108 (in Chinese).

Wang, C.-Y., Hwang, W.-T., Cochrane, G.R., 1994. Tectonic dewatering and mechanics of protothrust zones: example from the Cascadia accretionary margin. Journal of Geophysical Research 99, 20043-20050.

Wu, F., Rau, R.-J., Salzberg, D., 1997. Taiwan orogeny: thin-skinned or lithospheric collision? Tectonophysics $274,191-220$.

Wu, S.-H., Lin, C.-Y., Lin, L.-H., Oung, J.-N., 1993. Hydrocarbon correlation in the Central Uplifted Zone, Tainan basin. Bulletin of Exploration and Production, Taiwan CPC Corporation, 16, pp. 308-329 (in Chinese).

Yamazaki, T., Okamura, Y., 1989. Subducting seamounts and deformation of overriding forearc wedges around Japan. Tectonophysics 207-229.

Yang, T.F., Tien, J.L., Chen, C.-H., Lee, T., Punongbayan, R.S., 1995. Fission-track dating of volcanics in the northern part of the Taiwan-Luzon arc, eruption ages and evidence for crustal contamination. Journal of Southeast Asian Earth Sciences 11, 81-93.

Yeh, I.-C., Hsu, S.-K., 2004. Crustal structures of the northernmost South China Sea: Seismic reflection and gravity modeling. Marine Geophysical Researches 25, 45-61.

Yu, S.-B., Chen, H.-Y., Kuo, L.-C., 1997. Velocity field of GPS stations in the Taiwan area. Tectonophysics 274, 41-59. 